\title{
Cancer-associated IDH2 mutants drive an acute myeloid leukemia that is susceptible to Brd4 inhibition
}

\author{
Chong Chen, ${ }^{1}$ Yu Liu, ${ }^{1}$ Chao Lu, ${ }^{1,2}$ Justin R. Cross, ${ }^{3}$ John P. Morris IV, ${ }^{1}$ Aditya S. Shroff, ${ }^{1}$ \\ Patrick S. Ward, ${ }^{1,2}$ James E. Bradner, ${ }^{4}$ Craig Thompson, ${ }^{1}$ and Scott W. Lowe ${ }^{1,5,6}$ \\ ${ }^{1}$ Cancer Biology and Genetics Program, Memorial Sloan-Kettering Cancer Center, New York, New York 10065, USA; ${ }^{2}$ Cell and \\ Molecular Biology Graduate Group, Perelman School of Medicine, University of Pennsylvania, Philadelphia, Pennsylvania \\ 19104, USA; ${ }^{3}$ Donald B. and Catherine C. Marron Cancer Metabolism Center, Memorial Sloan-Kettering Cancer Center, \\ New York, New York 10065, USA; ${ }^{4}$ Department of Medicine, Harvard Medical School, Boston, Massachusetts 02115, USA; \\ ${ }^{5}$ The Howard Hughes Medical Institute, Memorial Sloan-Kettering Cancer Center, New York, New York 10065, USA
}

\begin{abstract}
Somatic mutations in the isocitrate dehydrogenase (IDH) genes IDH1 and IDH2 occur frequently in acute myeloid leukemia (AML) and other cancers. These genes encode neomorphic proteins that produce the presumed oncometabolite 2-hydroxyglutarate (2-HG). Despite the prospect of treating AML and other cancers by targeting IDH mutant proteins, it remains unclear how these mutants affect tumor development and maintenance in vivo, and no cancer models exist to study the action of IDH2 mutants in vivo. We show that IDH2 mutants can cooperate with oncogenic Flt3 or Nras alleles to drive leukemia in mice by impairing the differentiation of cells of the myeloid lineage. Pharmacologic or genetic inhibition of IDH2 triggers the differentiation and death of AML cells, albeit only with prolonged IDH2 inhibition. In contrast, inhibition of the bromodomain-containing protein Brd4 triggers rapid differentiation and death of IDH2 mutant AML. Our results establish a critical role for mutant IDH2 in leukemogenesis and tumor maintenance and identify an IDH-independent strategy to target these cancers therapeutically.
\end{abstract}

[Keywords: AML; Brd4 inhibition; IDH mutants; targeted therapy; tumor maintenance]

Supplemental material is available for this article.

Received July 15, 2013; revised version accepted August 23, 2013.

Acute myeloid leukemia (AML) is a heterogeneous cancer involving the accumulation of immature cells of the myeloid lineage (Shih et al. 2012; The Cancer Genome Atlas Research Network 2013). Genomic and functional studies have identified two broad classes of mutations that cooperate during AML development (Kelly and Gilliland 2002; Takahashi 2011). Class I mutations confer a proliferative and/or survival advantage of hematopoietic stem and progenitor cells (HSPCs) and include activating mutations in NRAS or KRAS, loss of the Ras-GAP NF1, or upstream activation of RAS signaling through mutations affecting the FLT3 receptor tyrosine kinase. Class II mutations promote self-renewal and block the differentiation of HSPCs. Such mutations include translocations involving the $M L L 1$ gene or the $\mathrm{t}(8: 21)$ fusion involving AML1-ETO. Alone, class I mutations tend to trigger chronic myeloid leukemia-like diseases, whereas class II mutations lead to a myelodysplastic syndrome (MDS)-

${ }^{6}$ Corresponding author

E-mail lowes@mskcc.org

Article is online at http://www.genesdev.org/cgi/doi/10.1101/gad.226613.113. like state. Although an oversimplification, as a rule, class I and class II mutations cooperate to drive AML, leading to the aberrant proliferation and suppressed differentiation that are hallmarks of this disease.

Currently, most AML patients are treated with highdose chemotherapy involving cytarabine (ara-C) and an anthracycline, a highly toxic drug combination to which $>70 \%$ of patients develop resistance. However, the nature of certain genes mutated in AML suggests strategies for treating patients with molecularly targeted agents. For example, internal tandem duplication (ITD) mutations in Flt3 lead to constitutive activation of its tyrosine kinase activity, and drugs targeting these mutations are in clinical trials (Stirewalt and Radich 2003; Leung et al. 2013). Similarly, MEK inhibitors, which interfere with RAS effector mechanisms, show efficacy in certain preclinical models (Lauchle et al. 2009). Finally, inhibitors of DOT1L, a histone methyltransferase needed for the oncogenic activity of MLL fusion oncoproteins, are entering clinical trials (Bernt et al. 2011; Daigle et al. 2011). Such therapies require that leukemia remains dependent on the targeted oncogene or pathway, which is often difficult 
to predict a priori. Still, not all novel AML targets directly interfere with oncogenic drivers or their downstream effectors. For example, the BET family member Brd4, which is not mutated in $\mathrm{AML}$, has been identified as a target in AML owing to its ability to sustain a Mycdependent self-renewal program activated by certain AML drivers (Dawson et al. 2011; Zuber et al. 2011b). Regardless of their mode of action, genetically and pathologically accurate mouse models of AML have been important in informing target development (Bernt et al. 2011; Zuber et al. 2011b).

Recently, somatic mutations in the isocitrate dehydrogenase (IDH) genes IDH1 and IDH2 have been identified at high frequency in AML and other tumor types (Parsons et al. 2008; Mardis et al. 2009; Yan et al. 2009; Amary et al. 2011; The Cancer Genome Atlas Research Network 2013). These genes encode key metabolic enzymes that convert isocitrate to $\alpha$-ketoglutarate $(\alpha-\mathrm{KG})$. IDH mutations mainly impact certain active site residues (e.g., $\mathrm{IDH} 1^{\mathrm{R} 132}$, IDH2 $2^{\mathrm{R} 140}$, or $\mathrm{IDH} 2^{\mathrm{R} 172}$, resulting in loss of normal enzymatic function and the acquisition of a neomorphic activity that enables the mutant proteins to reduce $\alpha$-KG to 2-hydroxyglutarate (2-HG) (Dang et al. 2009; Ward et al. 2010). The presumptive "oncometabolite" 2-HG can competitively inhibit multiple $\alpha-\mathrm{KG}$ dependent dioxygenases, including key epigenetic regulators such as histone demethylases and the DNAdemethylating TET proteins (Figueroa et al. 2010; Xu et al. 2011). Consequently, IDH mutants are associated with dramatic chromatin abnormalities, including globally altered histone and DNA methylation (Figueroa et al. 2010; Lu et al. 2012; Turcan et al. 2012). In the hematopoietic system and other cell types, these changes are associated with a differentiation block (Koivunen et al. 2012; Lu et al. 2012; Sasaki et al. 2012; Turcan et al. 2012).

The neomorphic action of IDH mutant proteins has created enthusiasm for targeting these enzymes with novel anti-cancer agents, and early studies using small molecules capable of inhibiting IDH1 $1^{\mathrm{R} 132 \mathrm{H}}$ and IDH2 ${ }^{\mathrm{R} 140 \mathrm{Q}}$ show some activity (Rohle et al. 2013; Wang et al. 2013). Still, there is a paucity of data documenting the oncogenic effects of IDH mutants on the development and maintenance of bona fide malignancies. On one hand, IDH2 mutants block the differentiation of cultured HSPCs (Figueroa et al. 2010), which accumulate in the hematopoietic compartment of mice expressing IDH $1^{\mathrm{R} 132 \mathrm{H}}$ (Sasaki et al. 2012). Also, enforced expression of this mutant can promote cytokine-independent growth and block the differentiation of an established erythroleukemic cell line in vitro (Losman et al. 2013). Still, in vivo models whereby IDH mutants drive a fully malignant disease have been lacking.

In this study, we describe a new mouse model in which IDH2 mutants cooperate with other lesions to drive an aggressive AML that accurately recapitulates features of the human disease. We further use this system to study the basis of IDH-mediated oncogenesis and as a preclinical model for testing novel therapies.

\section{Results}

IDH2 mutants cooperate with Flt3-ITD or NrasG12D to promote leukemia

Considering evidence that IDH mutations can block the differentiation of HSPCs (Figueroa et al. 2010; Sasaki et al. 2012), we hypothesized that they might act as canonical class II mutations and thus could cooperate with class I mutations to promote AML. We chose mouse models incorporating two common class I mutations observed in human AML: FLT3-ITD (Nakao et al. 1996) and Nras ${ }^{G 12 D}$ (Schubbert et al. 2007). Flt3-ITD knock-in mice develop a chronic myelomonocytic leukemia that never progresses to AML (Lee et al. 2007; Chu et al. 2012), whereas Mx1-mediated activation of a latent "lox-stop-lox" Nras ${ }^{G 12 D}$ allele (Haigis et al. 2008) in hematopoietic cells results in a myeloproliferative disorder (Li et al. 2011; Wang et al. 2011).

We applied a mosaic mouse modeling approach in which HSPCs are isolated from 5-fluorouracil (5-FU)treated Flt3-ITD mice, transduced with retroviral vectors expressing IDH2 mutants or a vector control, and then assessed for tumorigenic potential following transplantation into sublethally irradiated syngeneic recipient mice (Schmitt et al. 2002). For experiments involving Nras ${ }^{G 12 D}$, mice were pretreated with polyinosinic:polycytidylic acid (pIpC) to trigger cre-mediated oncogene activation (Supplemental Fig. 1A). Immunoblotting of protein extracts obtained from sorted $\mathrm{GFP}^{+} \mathrm{HSPC}$ confirmed expression of IDH2 wild-type and mutant proteins (Supplemental Fig. 1B). Gas chromatography-mass spectrometry (GC-MS) analysis revealed that 2-HG levels were elevated in HSPCs expressing $\mathrm{IDH} 2^{\mathrm{R} 140 \mathrm{Q}}$ and $\mathrm{IDH} 2^{\mathrm{R} 172 \mathrm{~K}}$ but not wild-type IDH2, confirming that the mutant alleles function as expected (Supplemental Fig. 1C).

Recipients of HSPCs expressing Flt3-ITD or Nras ${ }^{\text {G12D }}$ together with either IDH2 $2^{\mathrm{R} 140 \mathrm{Q}}$ or IDH2 $2^{\mathrm{R} 172 \mathrm{~K}}$ displayed significantly reduced survival compared with recipients of HSPCs expressing Flt3-ITD or Nras ${ }^{\mathrm{G} 12 \mathrm{D}}$ transduced with empty vector or wild-type IDH2 (Fig. 1A,B). Recipients of Flt3-ITD;IDH2 ${ }^{\mathrm{R} 140 \mathrm{Q}}$ - and Flt3-ITD;IDH2 ${ }^{\mathrm{R} 172 \mathrm{~K}}$ expressing HSPCs died with a similarly short latency after transplantation (median leukemia-free survival $=97 \mathrm{~d}$ ); similarly, both $\mathrm{Nras}^{\mathrm{G} 12 \mathrm{D}}$; $\mathrm{IDH} 2^{\mathrm{R} 140 \mathrm{Q}}$ - and $\mathrm{Nras}^{\mathrm{G} 12 \mathrm{D}}$; $\mathrm{IDH} 2^{\mathrm{R} 172 \mathrm{~K}}$-expressing HSPC recipients also showed accelerated disease onset, although in this instance, the effect of $\mathrm{IDH} 2^{\mathrm{R} 140 \mathrm{Q}}$ was less potent than $\mathrm{IDH} 2^{\mathrm{R} 172 \mathrm{~K}}$ (median leukemia-free survival $=178 \mathrm{~d}$ for $\mathrm{IDH} 2^{\mathrm{R} 140 \mathrm{Q}}$ vs. $98 \mathrm{~d}$ for $\mathrm{IDH} 2^{\mathrm{R} 172 \mathrm{~K}} ; P<0.0001$ ) (Fig. 1B). Complete blood counts (CBCs) showed that all IDH2 ${ }^{\mathrm{R} 140 \mathrm{Q}}$ and $\mathrm{IDH} 2^{\mathrm{R} 172 \mathrm{~K}}$ recipients displayed leukocytosis (Fig. 1C,D), anemia (Fig. 1E,F), and gross splenomegaly (Fig. 1G). Importantly, disease could be transferred to secondary recipients by transplanting bone marrow (BM) cells derived from moribund mice, indicating that neoplastic cells arising in the presence of $\mathrm{IDH} 2^{\mathrm{R} 140 \mathrm{Q}}$ or $\mathrm{IDH} 2^{\mathrm{R} 172 \mathrm{~K}}$ were fully malignant (Fig. $1 \mathrm{H}$ ).

\section{IDH2 mutations drive aggressive AML}

To further characterize the hematopoietic malignancy induced by each IDH2 mutant, we subjected moribund 

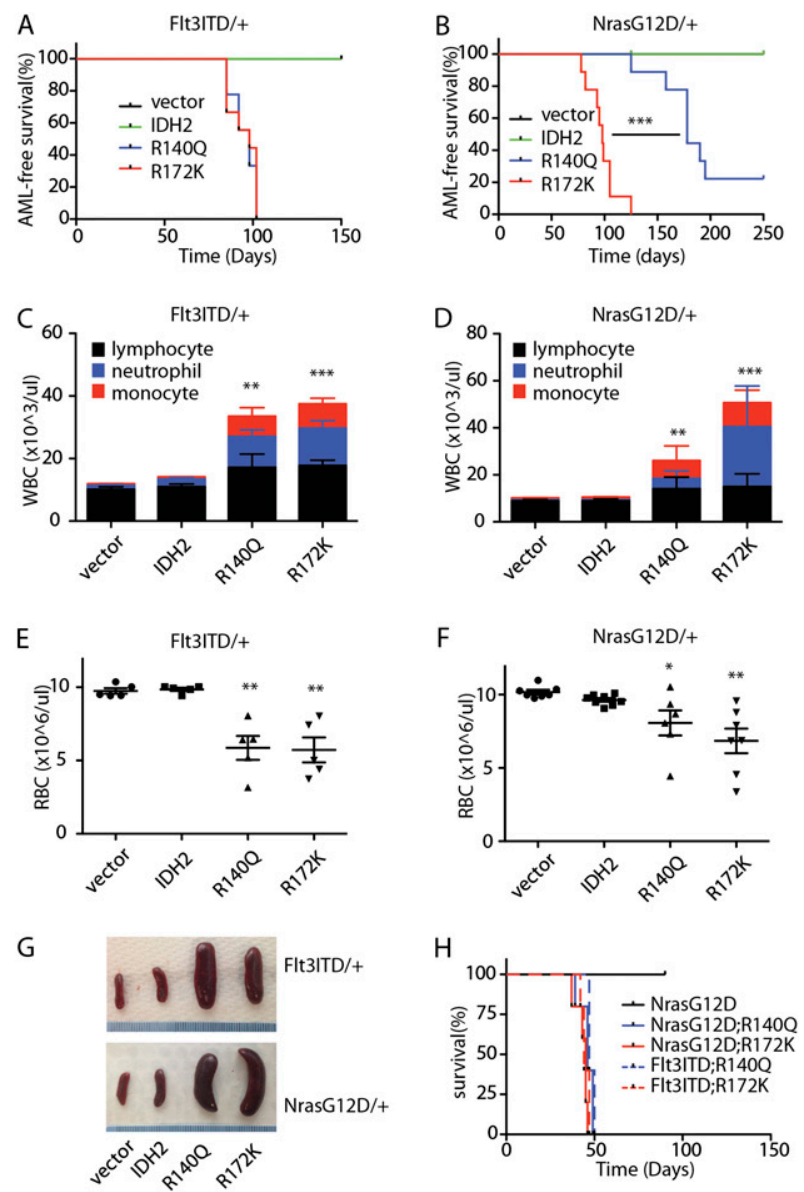

Figure 1. IDH2 mutants cooperate with class I mutations to promote leukemia. (A) Kaplan-Meier survival curve of mice transplanted with Flt3-ITD HSPCs transduced with empty MSCV-IRES-GFP vector (pMIG), IDH2 wild type (WT), or mutants $\left(\mathrm{IDH} 2^{\mathrm{R} 140 \mathrm{Q}}\right.$ and $\left.\mathrm{IDH} 2^{\mathrm{R} 172 \mathrm{~K}}\right) . n=9$. (B) Kaplan-Meier survival curve of mice transplanted with Nras ${ }^{\text {G12D }}$ HSPCs transduced with empty vector (pMIG), IDH2 wild type, or mutants $\left(\mathrm{IDH} 2^{\mathrm{R} 140 \mathrm{Q}}\right.$ and $\left.\mathrm{IDH} 2^{\mathrm{R} 172 \mathrm{~K}}\right) . n=9$. (C) White blood cell (WBC) counts of mice transplanted with Flt3-ITD HSPCs transduced with empty vector (pMIG), IDH2 wild type, or mutants $\left(\mathrm{IDH} 2^{\mathrm{R} 140 \mathrm{Q}}\right.$ and IDH2 $2^{\mathrm{R} 172 \mathrm{~K}}$ ) at $12 \mathrm{wk}$ after transplantation. $n=5$. (D) WBC counts of mice transplanted with Nras ${ }^{\mathrm{G} 12 \mathrm{D}}$ HSPCs transduced with empty vector (pMIG), IDH2 wild type, or mutants $\left(\mathrm{IDH} 2^{\mathrm{R} 140 \mathrm{Q}}\right.$ and $\mathrm{IDH} 2^{\mathrm{R} 172 \mathrm{~K}}$ ) at 12 wk after transplantation. $n=5$. $(E)$ Red blood cell $(\mathrm{RBC})$ counts of mice transplanted with Flt3-ITD HSPCs transduced with empty vector (pMIG), IDH2 wild type, or mutants (IDH2 ${ }^{\mathrm{R} 140 \mathrm{Q}}$ and IDH2 ${ }^{\mathrm{R} 172 \mathrm{~K}}$ ) at 12 wk after transplantation. $n=5 .(F) \mathrm{RBC}$ counts of mice transplanted with Nras ${ }^{\mathrm{G} 12 \mathrm{D}}$ HSPCs transduced with empty vector (pMIG), IDH2 wild type, or mutants (IDH2 ${ }^{\mathrm{R} 140 \mathrm{Q}}$ and $\mathrm{IDH}^{\mathrm{R} 172 \mathrm{~K}}$ ) at $12 \mathrm{wk}$ after transplantation. $n=5$. $(G)$ Representative pictures of the spleens of recipient mice transplanted with Flt3-ITD or Nras ${ }^{\text {G12D }}$ HSPCs transduced with empty vector (pMIG), IDH2 wild type, or mutants (IDH2 ${ }^{\mathrm{R} 140 \mathrm{Q}}$ and IDH2 ${ }^{\mathrm{R} 172 \mathrm{~K}}$ ). (H) Kaplan-Meier survival curve of the secondary recipient mice transplanted with Flt3-ITD or Nras ${ }^{\text {G12D }}$ HSPCs transduced with $\mathrm{IDH} 2$ wild type or mutants (IDH2 ${ }^{\mathrm{R} 140 \mathrm{Q}}$ and $\left.\mathrm{IDH} 2^{\mathrm{R} 172 \mathrm{~K}}\right) \cdot n=5 .\left(^{\star}\right)$ $\left.\left.P<0.05 ;\left.\right|^{\star \star}\right) P<0.01 ;\left.\right|^{\star \star \star}\right) P<0.001$. animals to histopathological analyses and immunophenotyping. At the time of sacrifice, all recipients of HSPCs harboring Flt3-ITD or Nras ${ }^{\text {G12D }}$ and an IDH2 mutant contained numerous circulating blasts in the peripheral blood (Fig. 2A). Leukemic cells replaced normal hematopoietic cells within the BM (Fig. 2B) and spleen and disseminated to normally nonhematologic organs such as the liver (Supplemental Fig. 2A,B). Flow cytometry revealed that all leukemic cells expressed mutant IDH2, indicated by GFP expression (Supplemental Fig. 3). Whether obtained from the spleen or BM, they expressed the myeloid marker Mac-1 and/or c-kit, a marker of more immature myeloid progenitors (MPs) (Fig. 2C,D,G).

Peripheral blood from recipient mice transplanted with HSPCs expressing the control vector or one encoding wild-type IDH 2 contained mostly $\mathrm{CD}^{+}$or $\mathrm{Thy}^{+}{ }^{+} \mathrm{T}$ cells and $\mathrm{B} 220^{+}$or $\mathrm{CD} 19^{+} \mathrm{B}$ cells, which is consistent with the cellular composition of blood from nonleukemic mice (Fig. 2E,H). In contrast, the peripheral blood from mice bearing leukemia driven by IDH2 $2^{\mathrm{R} 140 \mathrm{Q}}$ or IDH $2^{\mathrm{R} 172 \mathrm{~K}}$ was overrun with $\mathrm{CD}^{-} \mathrm{B}_{2} 20^{-} \mathrm{Macl}^{+}$or $\mathrm{Thy}^{-} \mathrm{CD}^{-}{ }^{-}$ $\mathrm{Macl}^{+}$cells (Fig. 2F,I). Taken together, these features indicate that IDH2 mutants in combination with Flt3ITD or NrasG12D drive disease resembling human AML.

In vitro studies indicate that the high 2-HG levels produced by IDH2 mutants can impair the functions of TET proteins that convert 5 -methylcytosine $(5 \mathrm{mC})$ to 5 -hydroxymethylcytosine $(5 \mathrm{hmC})$, resulting in a decrease of $5 \mathrm{hmC}$ levels (Figueroa et al. 2010). Accordingly, murine AMLs triggered by either IDH $2^{\mathrm{R} 140 \mathrm{Q}}$ or $\mathrm{IDH} 2^{\mathrm{R} 172 \mathrm{~K}}$ showed a marked increase in $2-\mathrm{HG}$ production relative to nonleukemic BM, the immortalized myeloid cell line 32D, and AML induced by other oncogenes (Fig. 3A). Interestingly, although in vitro studies indicate that $\mathrm{IDH} 2^{\mathrm{R} 172 \mathrm{~K}}$ produces more 2-HG than IDH2 ${ }^{\mathrm{R} 140 \mathrm{Q}}$ (Ward et al. 2013), the 2-HG levels present in Flt3-ITD;IDH2 ${ }^{\mathrm{R} 140 \mathrm{Q}}$ and Flt3-ITD;IDH2 $2^{\mathrm{R} 172 \mathrm{~K}}$ AMLs were comparable, perhaps owing to the lower expression of IDH2 $2^{\mathrm{R} 172 \mathrm{~K}}$ than that of $\mathrm{IDH} 2^{\mathrm{R} 140 \mathrm{Q}}$ (data not shown). Analysis of DNA methylation by dot blotting of normal and leukemia DNA showed no significant difference in the global levels of $5 \mathrm{mC}$ in AMLs expressing IDH2 mutants. However, consistent with their ability to inhibit TET proteins, IDH2 mutant leukemia displayed a massive reduction in $5 \mathrm{hmC}$ levels (Fig. 3B).

$I D H 2^{R 172}$ mutations are associated with poor prognosis in AML patients, while the clinical effects of $I D H 2^{R 140}$ mutations are controversial (Marcucci et al. 2010; Paschka et al. 2010; Patel et al. 2012). As underlying differences in survival of patients with different AML genotypes can be linked to treatment response (Zuber et al. 2009; Patel et al. 2012), we asked whether IDH2 mutant AMLs were intrinsically sensitive or resistant to ara-C chemotherapy. Consistent with previous reports (Zuber et al. 2009), Nras ${ }^{\text {G12D }}$;AML1-ETO leukemic cells were much more sensitive to ara-C than $\mathrm{Nras}^{\mathrm{G} 12 \mathrm{D}}$;MLL-AF9 leukemic cells in a $3-\mathrm{d}$ treatment assay $\left(\mathrm{IC}_{50}=39\right.$ vs. $63 \mathrm{nM} ; P=$ $0.03)$. In contrast, both $\mathrm{Nras}^{\mathrm{G} 12 \mathrm{D}} ; \mathrm{IDH} 2^{\mathrm{R} 140 \mathrm{Q}}$ and Nras ${ }^{\mathrm{G} 12 \mathrm{D}}$; $\mathrm{IDH} 2{ }^{\mathrm{R} 172 \mathrm{~K}}$ AML cells were highly resistant to ara-C in vitro $\left(\mathrm{IC}_{50}=93\right.$ and $345 \mathrm{nM}$, respectively; $P=0.0001$ for 
A

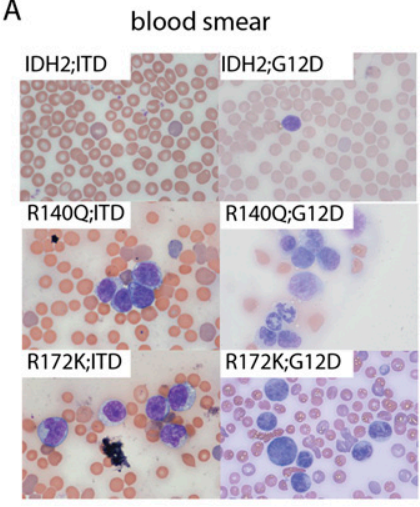

D

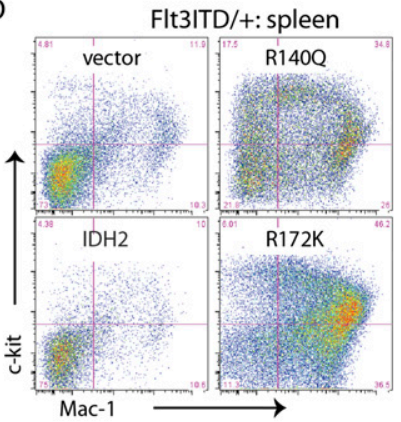

G

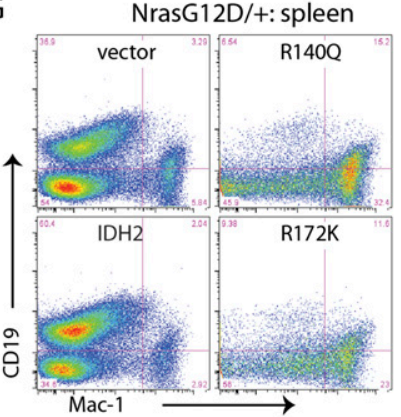

B

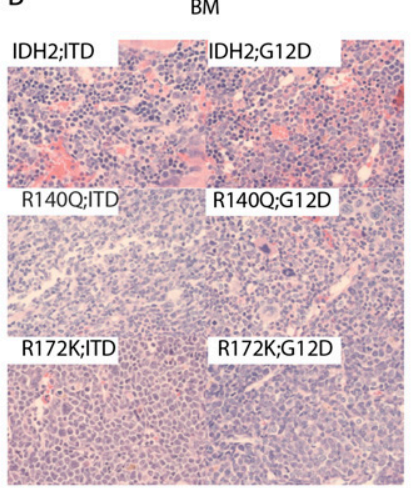

E

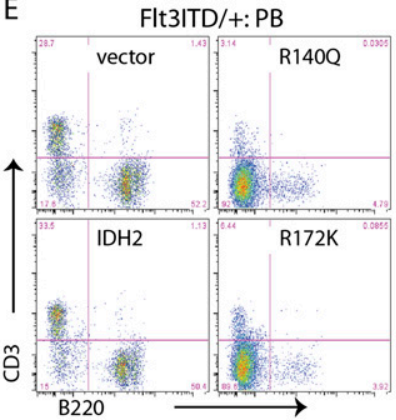

$\mathrm{H}$

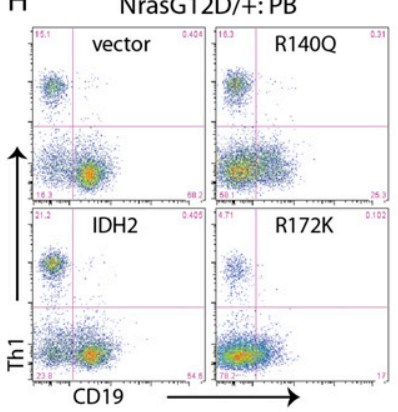

C

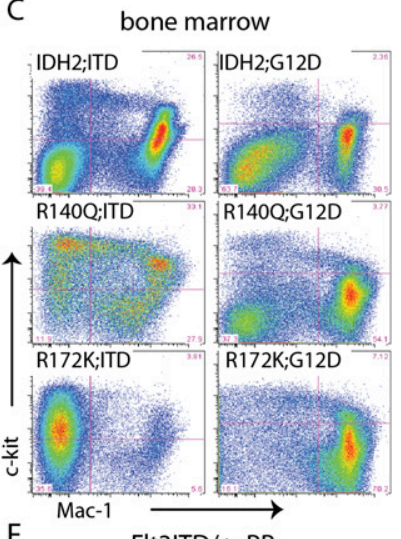

F
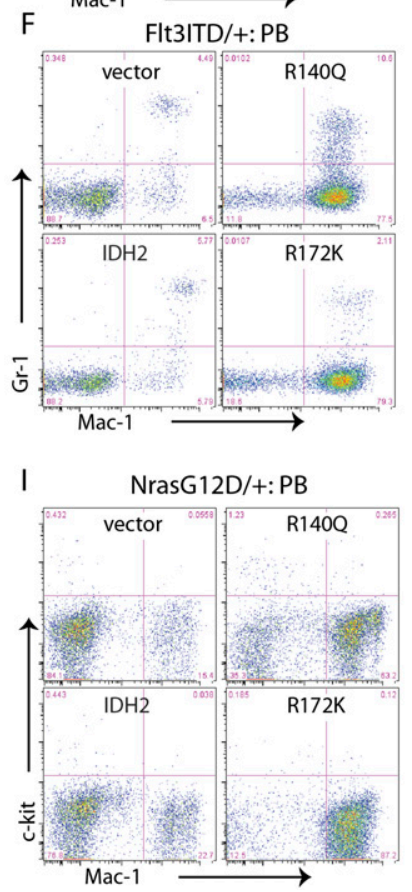

Figure 2. $\mathrm{IDH} 2$ mutations result in AML. $(A)$ Blood smear of recipient mice transplanted with Flt3-ITD or Nras ${ }^{\mathrm{G} 12 \mathrm{D}}$ HSPCs transduced with IDH2 wild type (WT) or mutants (IDH2 $2^{\mathrm{R} 140 \mathrm{Q}}$ and $\left.\mathrm{IDH} 2^{\mathrm{R} 172 \mathrm{~K}}\right) .(B) \mathrm{H} \& \mathrm{E}$ staining of $\mathrm{BM}$ sections $(400 \times)$ of recipient mice transplanted with IDH2 wild-type- or mutant-expressing cells. $(C)$ Representative flow plots of BM cells from recipient mice transplanted with Flt3-ITD or Nras ${ }^{\mathrm{G} 12 \mathrm{D}}$ HSPCs transduced with $\mathrm{IDH} 2$ wild type, or mutants $\left(\mathrm{IDH} 22^{\mathrm{R} 140 \mathrm{Q}}\right.$ and $\left.\mathrm{IDH} 2^{\mathrm{R} 172 \mathrm{~K}}\right) \cdot(D)$ Representative flow plots of splenocytes stained with Mac-1 and c-kit of recipients transplanted with Flt3-ITD cells transduced with empty vector, IDH2 wild type, or mutants $\left(\mathrm{IDH} 2{ }^{\mathrm{R} 140 \mathrm{Q}}\right.$ and $\left.\mathrm{IDH} 2^{\mathrm{R} 172 \mathrm{~K}}\right)$. (E) Representative flow plots of peripheral blood stained with $\mathrm{B} 220$ and $\mathrm{CD} 3$ of recipients transplanted with Flt3ITD cells transduced with empty vector, IDH2 wild type, or mutants $\left(\mathrm{IDH} 2^{\mathrm{R} 140 \mathrm{Q}}\right.$ and $\left.\mathrm{IDH} 2^{\mathrm{R} 172 \mathrm{~K}}\right)$. (F) Representative flow plots of peripheral blood stained with Mac-1 and Gr-1 of recipients transplanted with Flt3-ITD cells transduced with empty vector, IDH2 wild type, or mutants $\left(\mathrm{IDH} 2^{\mathrm{R} 140 \mathrm{Q}}\right.$ and $\left.\mathrm{IDH} 2^{\mathrm{R} 172 \mathrm{~K}}\right) .(G)$ Representative flow plots of splenocytes stained with Mac-1 and CD19 of recipients transplanted with Nras ${ }^{\mathrm{G} 12 \mathrm{D}}$ cells transduced with empty vector, IDH2 wild type, or mutants (IDH2 $2^{\mathrm{R} 140 \mathrm{Q}}$ and $\mathrm{IDH} 2^{\mathrm{R} 172 \mathrm{~K}}$ ). $(H)$ Representative flow plots of peripheral blood stained with CD19 and Thy1 of recipients transplanted with Nras ${ }^{\text {G12D }}$ cells transduced with empty vector, IDH2 wild type, or mutants $\left(\mathrm{IDH} 2^{\mathrm{R} 140 \mathrm{Q}}\right.$ and $\left.\mathrm{IDH} 2^{\mathrm{R} 172 \mathrm{~K}}\right)$. (I) Representative flow plots of peripheral blood stained with Mac-1 and c-kit of recipients transplanted with Nras ${ }^{\mathrm{G} 12 \mathrm{D}}$ cells transduced with empty vector, $\mathrm{IDH} 2$ wild type, or mutants (IDH2 ${ }^{\mathrm{R} 140 \mathrm{Q}}$ and $\mathrm{IDH} 2^{\mathrm{R} 172 \mathrm{~K}}$ ).

$\mathrm{Nras}^{\mathrm{G} 12 \mathrm{D}}$;IDH2 ${ }^{\mathrm{R} 140 \mathrm{Q}}$ vs. Nras ${ }^{\mathrm{G} 12 \mathrm{D}} ; \mathrm{AML1-ETO} ; P<0.0001$ for $\mathrm{Nras}^{\mathrm{G} 12 \mathrm{D}} ; \mathrm{IDH} 2^{\mathrm{R} 172 \mathrm{~K}}$ vs. $\mathrm{Nras}^{\mathrm{G} 12 \mathrm{D}}$;AML1-ETO). Nras ${ }^{\mathrm{G} 12 \mathrm{D}}$; $\mathrm{IDH} 2{ }^{\mathrm{R} 172 \mathrm{~K}}$ AML cells were even more resistant to ara-C than $\mathrm{Nras}^{\mathrm{G} 12 \mathrm{D}} ; \mathrm{IDH} 2^{\mathrm{R} 140 \mathrm{Q}}$ AML cells $(P=0.0002)$, an intriguing observation in light of the poorer prognosis of patients with $I D H 2^{R 172}$ mutations (Fig. 3C). This resistance was more striking in vivo, where some ara-C-treated mice harboring IDH2 mutant AMLs died even earlier than vehicle-treated controls (Fig. 3D). Therefore, IDH2 mutants can cooperate with class I mutations to promote AML with pathological, biological, and molecular features of the human disease.

IDH2 mutants are sufficient to suppress hematopoietic differentiation and alter DNA methylation in vivo

To determine whether the tumorigenic phenotype driven by mutant IDH2 might derive from their ability to impair 
Chen et al.
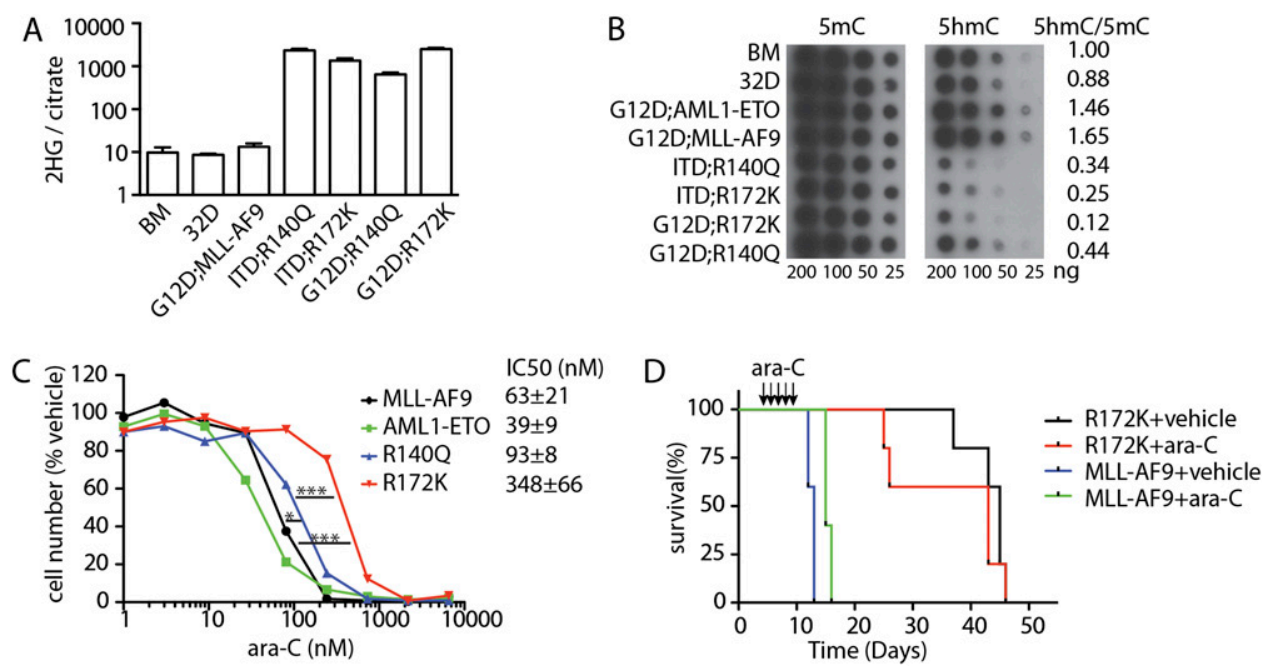

Figure 3. IDH2 mutant-induced AMLs display high 2-HG levels and altered DNA methylation and are chemoresistant. $(A)$ 2-HG levels in BM, 32D, and MLL-AF9 or IDH2 mutant-induced AMLs. $n=3-5$. (B) Representative dot blotting with antibodies against 5mC and $5 \mathrm{hmC}$ displaying DNA methylation of nonleukemic (BM and 32D) and leukemic cells. (C) Dose response of Nras ${ }^{\mathrm{G} 12 \mathrm{D}}$; ${ }_{\text {MLL-AF9, }}$ $\mathrm{Nras}^{\mathrm{G} 12 \mathrm{D}}$;AML1-ETO, Nras ${ }^{\mathrm{G} 12 \mathrm{D}}$;IDH2 ${ }^{\mathrm{R} 140 \mathrm{Q}}$, and $\mathrm{Nras}^{\mathrm{G} 12 \mathrm{D}} ; \mathrm{IDH} 2^{\mathrm{R} 172 \mathrm{~K}}$ leukemic cells to ara-C. Leukemic cells were treated with vehicle or $1-6000 \mathrm{nM}$ ara-C for 3 d. $n=4$. (D) Kaplan-Meier survival curve of mice transplanted with Nras ${ }^{\mathrm{G} 12 \mathrm{D}}$;MLL-AF9 or Nras ${ }^{\mathrm{G} 12 \mathrm{D}} ; \mathrm{IDH}^{\mathrm{R} 172 \mathrm{~K}}$ leukemic cells treated with ara-C or vehicle. $n=5$.

differentiation in vivo, we examined the impact of IDH2 mutants on hematopoiesis using a competitive reconstitution assay. Here, CD45.1 HSPCs were transduced with a control vector expressing GFP alone or together with GFP vectors encoding either wild-type IDH2, IDH2 ${ }^{\mathrm{R} 140 \mathrm{Q}}$, or IDH2 $2^{\mathrm{R} 172 \mathrm{~K}}$; the resulting populations were then mixed with CD45.2 BM cells as a competitive reference and transplanted into lethally irradiated CD45.1 mice (Fig. 4A). Peripheral blood, spleen, and BM from recipient animals were analyzed for cellular composition, 2-HG production, and changes in DNA methylation.

As expected, white blood cell (WBC) counts in mice receiving HSPCs transduced with empty or wild-type IDH2-expressing vector increased with time after transplantation (Supplemental Fig. 4A). Under these conditions, transplanted cells were able to reconstitute a normal hematopoietic compartment, which displayed the expected distributions of $\mathrm{Lin}^{-} \mathrm{Sca}^{+} \mathrm{c}-\mathrm{Kit}^{+}$(LSK) HSPCs, $\mathrm{Lin}^{-} \mathrm{Sca}^{-}$ c-Kit ${ }^{+}(\mathrm{MP})$, and other hematopoietic cells (Fig. 4B,D). If anything, empty vector and wild-type IDH2 appeared to confer a competitive disadvantage during hematopoietic reconstitution, as virtually no $\mathrm{GFP}^{+}$cells remained after $12 \mathrm{wk}$, with most cells being derived from untransduced or competitor cells (Fig. 4E).

Mice reconstituted with HSPCs expressing $\mathrm{IDH} 2^{\mathrm{R} 140 \mathrm{Q}}$ and $\mathrm{IDH} 2^{\mathrm{R} 172 \mathrm{~K}}$ showed a markedly different phenotype. Although at 4 wk post-transduction these mice retained WBC counts comparable with controls, by $12 \mathrm{wk}$, they showed significantly reduced WBC and had developed an anemia (Fig. 4F; Supplemental Fig. 4A) associated with significantly reduced BM cellularity (Fig. 4G). Nevertheless, IDH2 mutant cells $\left(\mathrm{GFP}^{+}\right)$predominated over controls $\left(\mathrm{GFP}^{-}\right)$, suggesting that these cells outcompeted and excluded the nontransduced and cotransplanted CD45.2 cells (Fig. 4E). These changes were associated with an increased fraction of $\mathrm{LSK}^{+}$and MPs in the BM (Fig. 4B-D). Although LSK cells expressing both IDH2 mutants showed slightly increased BrdU incorporation when compared with controls, the opposite occurred in the MP compartment, where IDH2 mutant MP cells displayed reduced BrdU incorporation (Fig. 4H,I). The reduced proliferation and increased percentage of MPs in recipients of IDH mutants were associated with a skewing of BM differentiation toward the myeloid lineage (Fig. 4D) comparable with phenotypes observed in $I D H 1^{R 132 H}$ knock-in mice (Sasaki et al. 2012). Thus, IDH2 mutant proteins block the differentiation of MP cells in vivo, leading to the accumulation of more immature cell populations.

As expected, BM cells derived from mice reconstituted with HSPCs expressing IDH2 $2^{\mathrm{R} 140 \mathrm{Q}}$ or $\mathrm{IDH} 2^{\mathrm{R} 172 \mathrm{~K}}$ contained high levels of 2-HG (Fig. 5A). In contrast to what has been observed in other systems (Xu et al. 2011; Lu et al. 2012), no obvious changes in the global abundance of methylated histones (H3K4me3, H3K9me3, and H3K27me3) were observed in BM cells expressing IDH2 mutants (Supplemental Fig. 5) relative to vetor-only or wild-type IDH4-expressing cells, raising the possibility that IDH mutants can have tissue-specific effects on chromatin biology and cell fate. Nevertheless, these BM cells showed significantly decreased $5 \mathrm{hmC}$ levels without overt changes in global $5 \mathrm{mC}$ levels (Fig. 5B), an effect that was also observed in c-kit-positive cells subjected to flow cytometry (Fig. 5C,D; Supplemental Fig. 5B). Overexpression of wild-type IDH2 did not have significant effects on $5 \mathrm{hmC}$ levels (Fig. 5B,D; Supplemental Fig. 5B). Hence, IDH2 mutants are sufficient to drive 2-HG production and alter DNA methylation during leukemogenesis. 
A
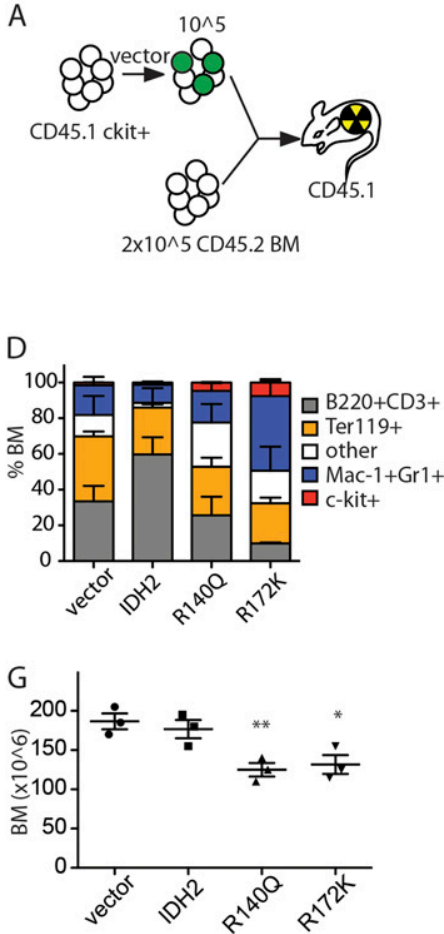
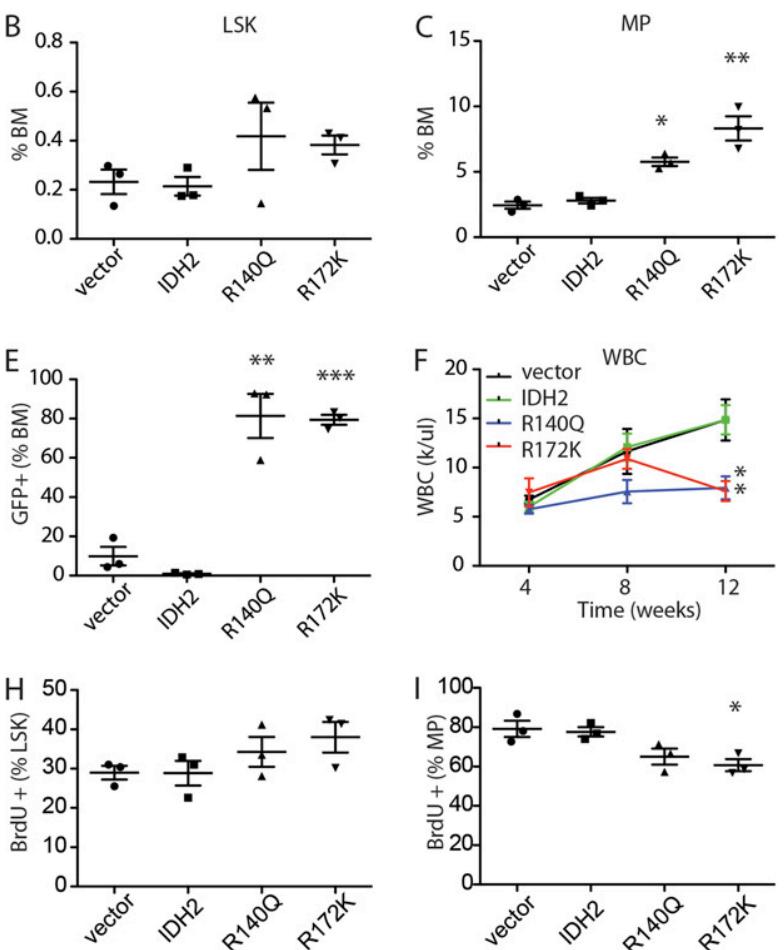

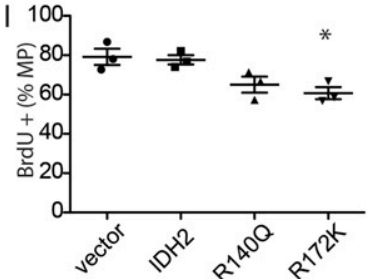

Figure 4. IDH2 mutations are sufficient to block differentiation of HSPCs and alter DNA methylation. $(A)$ Schematic diagram of competitive transplant assay. Vector refers to transduction of cells with empty MSCV-IRES-GFP vector or one coexpressing wild-type IDH2 or an IDH2 mutant. CD45.1 c-kit ${ }^{+}$HSPCs $\left(10^{5}\right)$ transduced with vectors were mixed with $2 \times 10^{5} \mathrm{CD} 45.2 \mathrm{BM}$ and transplanted into lethally irradiated CD45.1 recipient mice. (B) Percentage of $\operatorname{lin}^{-}$Sca- $1^{+} \mathrm{c}-\mathrm{kit}^{+}$(LSK) cells in the whole BM of recipient mice $12 \mathrm{wk}$ after transplantation. $n=3 .(C)$ Percentage of $\operatorname{lin}^{-}$Sca- $1^{-}$c-kit ${ }^{+}(\mathrm{MP})$ cells in the whole BM of recipient mice $12 \mathrm{wk}$ after transplantation. $n=3$. (D) Percentage of c-kit ${ }^{+}, \mathrm{Mac}^{+} 1^{+}$or $\mathrm{Gr}-1^{+}, \mathrm{B} 220^{+}$or $\mathrm{CD}^{+}$, and Ter119 ${ }^{+}$cells in the whole BM of recipient mice $12 \mathrm{wk}$ after transplantation. $n=3$. (E) Percentage of $\mathrm{GFP}^{+}$cells in the whole BM of recipient mice $12 \mathrm{wk}$ after transplantation. $n=3$. $(F)$ WBC counts of recipient mice with IDH2 wild-type- or mutant-expressing cells. $n=4-5$. $(G)$ BM cellularities of recipient mice with IDH2 wild-typeor mutant-expressing cells at $12 \mathrm{wk}$ after transplantation. $n=3 .(H)$ BrdU incorporation rate of LSK cells after $1 \mathrm{~d}$ of labeling. $n=3$. $(I)$ BrdU incorporation rate of MP cells after $1 \mathrm{~d}$ of labeling. $n=3$. Of note, in $B-G$, vector, IDH2, or IDH2 mutants refers to mice transplanted with HSPCs transduced with the indicated vector but does not necessarily indicate that all of the cells analyzed expressed the constructs. Specifically, while BM from mice transplanted with IDH2 mutant cells almost completely consisted of GFP ${ }^{+}$IDH mutant-expressing cells (shown in E), empty vector and wild-type IDH produced a competitive disadvantage, and BM consisted entirely of $\mathrm{GFP}^{-}$normal competitors at this time point.

\section{IDH2 mutants are required for leukemia maintenance}

The availability of IDH mutant-driven leukemia models enabled us to assess whether ongoing expression of IDH2 mutants and their product, 2-HG, were required for tumor maintenance. AGI-6780 is a commercially available small-molecule inhibitor that targets IDH $2^{\mathrm{R} 140 \mathrm{Q}}$ but not IDH2 $2^{\mathrm{R} 172 \mathrm{~K}}$ and has been shown to have anti-leukemic activity in human AML (Wang et al. 2013). To assess its activity against IDH2 mutant-driven murine AML, control Nras ${ }^{\mathrm{G} 12 \mathrm{D}}$;MLL-AF9 leukemia or Nras ${ }^{\mathrm{G} 12 \mathrm{D}}$ leukemias coexpressing IDH2 $2^{\mathrm{R} 140 \mathrm{Q}}$ or IDH2 $2^{\mathrm{R} 172 \mathrm{~K}}$ were treated with AGI-6780 in vitro, and 2-HG production, cellular proliferation, and differentiation were monitored. Within $2 \mathrm{~d}$, AGI-6780 inhibited 2-HG production in AML cells expressing $\mathrm{IDH} 2^{\mathrm{R} 140 \mathrm{Q}}$ but not control or $\mathrm{IDH} 2^{\mathrm{R} 172 \mathrm{~K}}$. expressing leukemia cells (Fig. 6A). Remarkably, this effect was associated with a 2 -wk proliferative burst that was unique to IDH2 $2^{\mathrm{R} 140 \mathrm{Q}}$-expressing AML (Fig. 6B), after which these cells ceased to proliferate and underwent differentiation (Fig. 6C,D). This proliferative burst and eventual differentiation have also been seen following AGI-6780 treatment of a human AML explant harboring the IDH2 $2^{\text {R140Q }}$ allele (Wang et al. 2013).

Small-molecule inhibitors of the IDH2 $2^{\mathrm{R} 172 \mathrm{~K}}$ protein are not currently available. To test its role in leukemia maintenance, we designed shRNA specifically targeting human IDH2, thus inhibiting only the exogenously transduced IDH2 mutant used in this model (Fig. 6E,F). Control (shRen, a potent shRNA targeting Renilla luciferase) and IDH2-specific shRNAs were cloned downstream from a tetracycline-responsive element and dsRed and retrovirally transduced into $\mathrm{IDH} 2$ mutant leukemia cells also expressing a rtTA transgene, thereby making the shRNAs doxycycline-inducible (Zuber et al. 2011a). Cells were treated with doxycycline and analyzed for the prevalence of the dsRed marker (and thus the competitive fitness of shRNA-expressing cells) over time.

As expected, IDH2 shRNAs had no effect on MLL-AF9driven AML. However, similar to the effects of AGI-6780, 
Chen et al.
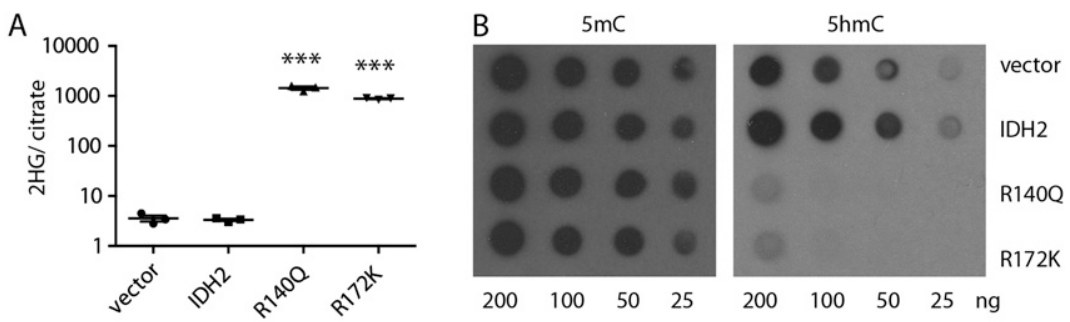

Figure 5. IDH2 mutants lead to abnormal DNA methylation in hematopoietic cells. (A) 2-HG levels in the whole BM cells of recipient mice. $n=3$. (B) Representative dot blots showing $5 \mathrm{mC}$ and $5 \mathrm{hmC}$ levels of whole BM genomic DNA. (C) Relative mean fluorescence intensity (MFI) of $5 \mathrm{hmC}$ in $\mathrm{GFP}^{+} \mathrm{BM}$ cells. $n=3$. (D) Relative MFI of $5 \mathrm{mC}$ in $\mathrm{GFP}^{+}$c-kit ${ }^{+}$BM cells. $n=3$.
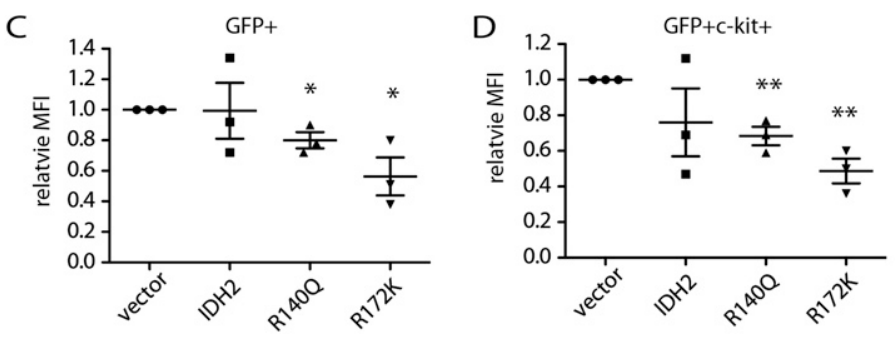

inhibition of $\mathrm{IDH} 2^{\mathrm{R} 172 \mathrm{~K}}$ by RNAi led to an initial enhanced proliferation and subsequent depletion of shRNAexpressing cells from the population (Fig. $6 \mathrm{H}$ ), an effect associated with myeloid differentiation (Fig. 6G). Thus, ongoing expression of IDH2 mutants is required to block differentiation, although long periods of IDH2 inhibition are required to reverse these effects. In principle, the delay in response may reflect the requirement for cell division to renormalize the epigenetic changes produced by mutant IDH2.

\section{IDH mutant AMLs rapidly differentiate in response to Brd4 inhibition}

The BET family protein BRD4 has been identified as a therapeutic target in AML produced by MLL fusion oncoproteins owing to its ability to sustain an aberrant self-renewal circuit controlled by Myc (Dawson et al. 2011; Zuber et al. 2011b). To test whether the aberrant self-renewal program produced by IDH2 mutants is also sensitive to Brd4 inhibition, we examined the impact of two independently validated Brd4 shRNAs (Zuber et al. $2011 \mathrm{~b}$ ) or the small-molecule Brd4 inhibitor JQ1 on leukemic cell proliferation, viability, differentiation, and Myc levels in IDH2 mutant AML. Cultured cells were infected with the doxycycline-inducible construct used above expressing either shRNAs targeting Brd4 or Renilla as a control. Brd4 suppression acutely reduced the competitive fitness of cultured $\mathrm{Nras}^{\mathrm{G} 12 \mathrm{D}} ;{ }^{\mathrm{IDH}} 2^{\mathrm{R} 172 \mathrm{~K}}$ cells compared with controls, suggesting that Brd4 is essential to maintain IDH2 mutant leukemia (Fig. 7A).

In parallel, we tested response to the small-molecule JQ1 in vitro. As expected, Nras ${ }^{\mathrm{G} 12 \mathrm{D}}$;MLL-AF9 AML cells were highly sensitive to JQ1 ( $\mathrm{IC}_{50}, 58 \mathrm{nM}$ ) (Zuber et al. 2011b), while Nras ${ }^{\mathrm{G} 12 \mathrm{D}}$;AML1-ETO AML cells were more resistant $\left(\mathrm{IC}_{50}, 1159 \mathrm{nM}\right)$. IDH mutant AMLs were even more sensitive to JQ1 than Nras ${ }^{\mathrm{G} 12 \mathrm{D}}$;MLL-AF9expressing cells $\left(\mathrm{IC}_{50}, 34 \mathrm{nM}\right.$ and $19 \mathrm{nM}$ for Nras ${ }^{\mathrm{G} 12 \mathrm{D}}$; $\mathrm{IDH} 2^{\mathrm{R} 140 \mathrm{Q}}$ and $\mathrm{Nras}{ }^{\mathrm{G} 12 \mathrm{D}} \mathrm{IDH} 2^{\mathrm{R} 172 \mathrm{~K}}$, respectively; $P=$ 0.01 for $\mathrm{Nras}^{\mathrm{G} 12 \mathrm{D}}$; IDH2 ${ }^{\mathrm{R} 140 \mathrm{Q}}$ vs. Nras ${ }^{\mathrm{G} 12 \mathrm{D}}$;MLL-AF9;
$P<0.0001$ for $\mathrm{Nras}^{\mathrm{G} 12 \mathrm{D}}{ }_{;} \mathrm{IDH} 2^{\mathrm{R} 172 \mathrm{~K}}$ vs. $\mathrm{Nras}^{\mathrm{G} 12 \mathrm{D}}{ }_{\text {;MLL-AF9| }}$ (Fig. 7B).

The hypersensitivity of IDH mutant AMLs to Brd4 inhibition was associated with rapid differentiation after either shRNA Brd4 knockdown or JQ1 treatment (Fig. 7C-E). Nevertheless, JQ1 treatment did not affect 2-HG levels in either IDH2 ${ }^{\mathrm{R} 140 \mathrm{Q}}$ or IDH2 $2^{\mathrm{R} 172 \mathrm{~K}}$ cells (Fig. $7 \mathrm{~F}$ ), perhaps indicating that Brd4 inhibition acts downstream from mutant IDH2 proteins and mediates its effects without directly affecting its neomorphic activity. However, as has been reported in MLL-AF9-driven AML, immunoblotting of IDH2 mutant AML lysates treated for $48 \mathrm{~h}$ with JQ1 revealed reduced levels of Myc (Fig. 7G). Therefore, IDH2 mutant AMLs are addicted to a Brd4driven, Myc-dependent, self-renewal program that can be inhibited by JQ1 treatment.

Although the pharmacologic properties of JQ1 are not ideal for in vivo studies (Matzuk et al. 2012), we tested its activity against IDH2 mutant AML in vivo. Mice were transplanted with $\mathrm{IDH} 2^{\mathrm{R} 172 \mathrm{~K}}$ AML and, upon engraftment, treated (day 5) with vehicle or $50 \mathrm{mg} / \mathrm{kg}$ per day JQ1 by gavage for 2 wk (Filippakopoulos et al. 2010; Zuber et al. 2011b). Leukemic cells were apparent in the peripheral blood in vehicle-treated mice at day 19 but completely absent in JQ1-treated animals (Fig. 7H). JQ1treated mice also displayed significantly improved erythropoiesis, leading to reduced anemia (Fig. 7I). While all vehicle-treated mice died within $3 \mathrm{~d}$ post-treatment, JQ1 treatment extended median survival to $18 \mathrm{~d}$ (Fig. 7J). Taken together, IDH mutant-driven AML is susceptible to Brd4 inhibition both in vitro and in vivo.

\section{Discussion}

A mouse AML model driven by IDH2 mutants suggests therapeutic approaches for AML treatment

In vivo cancer models are essential for understanding genetic alterations that contribute to oncogenesis and can provide preclinical systems for testing novel therapies. 
A

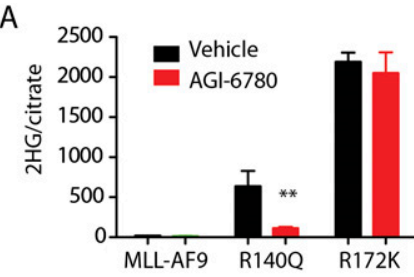

C

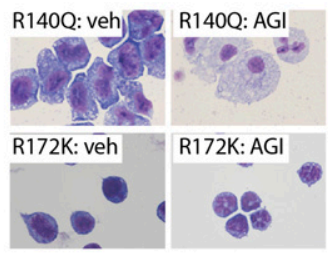

$\mathrm{E}$

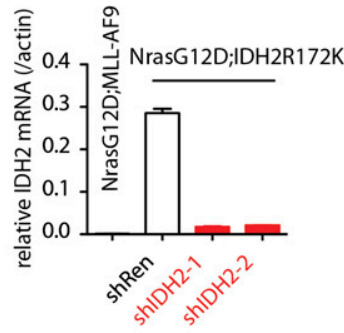

$\mathrm{F}$

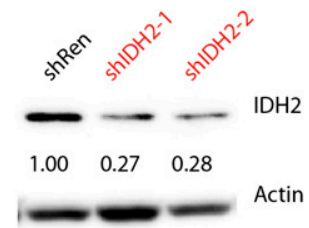

B
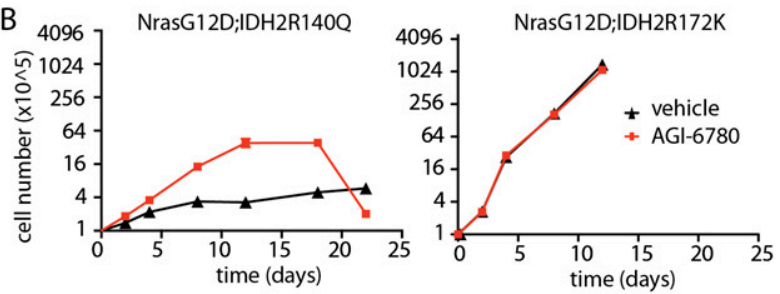

D

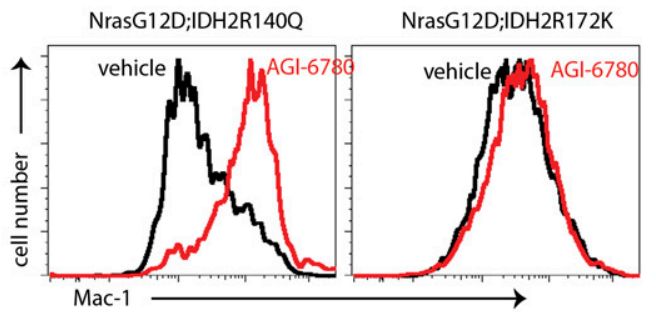

G
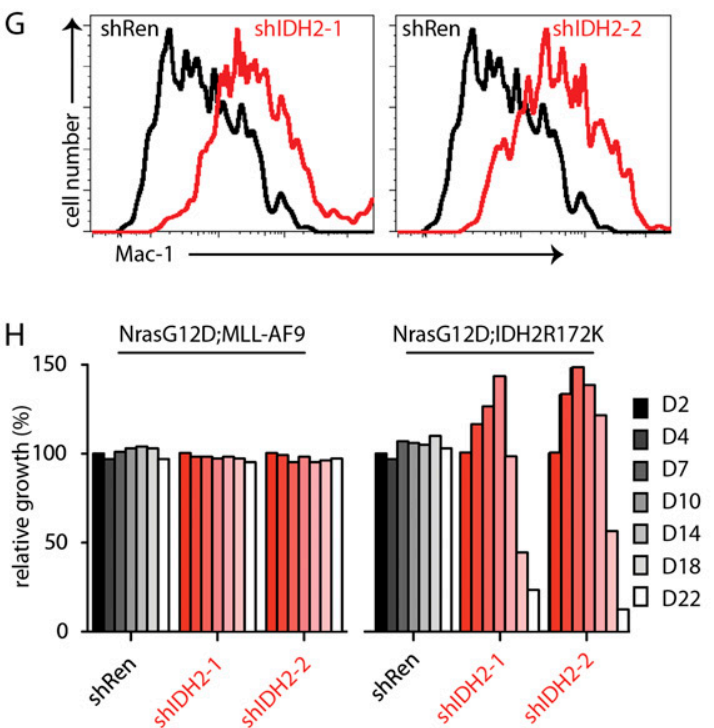

Figure 6. Inhibition of IDH2 mutants leads to loss of 2-HG and delayed differentiation. (A) 2-HG levels of leukemic cells treated with 5 $\mu \mathrm{M}$ AGI-6780 for $2 \mathrm{~d} . n=3$. (B) Growth of leukemic cells treated with $5 \mu$ M AGI-6780 or vehicle. $n=4$. $(C)$ Representative H\&E staining of cytospin of $\mathrm{Nras}^{\mathrm{G} 12 \mathrm{D}}$;IDH2 $2^{\mathrm{R} 140 \mathrm{Q}}$ and $\mathrm{Nras}^{\mathrm{G} 12 \mathrm{D}}$;IDH2 $2^{\mathrm{R} 172 \mathrm{~K}}$ leukemic cells treated with vehicle or $5 \mu M$ AGI-6780 at day 22 . $(D)$ Expression levels of Mac-1 by Nras ${ }^{\mathrm{G} 12 \mathrm{D}} ; \mathrm{IDH} 2^{\mathrm{R} 140 \mathrm{Q}}$ and $\mathrm{Nras}^{\mathrm{G} 12 \mathrm{D}}$;IDH2 ${ }^{\mathrm{R} 172 \mathrm{~K}}$ leukemic cells treated with vehicle or $5 \mu \mathrm{M}$ AGI-6780 at day 22. $(E)$ Transcript levels of hIDH2 in Nras ${ }^{\mathrm{G} 12 \mathrm{D}} ; \mathrm{IDH} 2^{\mathrm{R} 172 \mathrm{~K}}$ cells expressing shRen or shIDH2, normalized to actin mRNA. $n=4$. $(F)$ Western blot demonstrating hIDH2 knockdown in Nras ${ }^{\text {G12D }}$;DH2 ${ }^{\text {R172K }}$ leukemic cells by shRNAs against mutant IDH2. (G) Relative growth of NrasG12D;MLL-AF9 and Nras ${ }^{\mathrm{G} 12 \mathrm{D}}$;IDH2 ${ }^{\mathrm{R} 172 \mathrm{~K}}$ leukemic cells with shRen or shIDH2. $n=3$. $(H)$ Expression levels of Mac-1 by Nras ${ }^{\mathrm{G} 12 \mathrm{D}} ; \mathrm{IDH} 2^{\mathrm{R} 140 \mathrm{Q}}$ and Nras ${ }^{\mathrm{G} 12 \mathrm{D}} ; \mathrm{IDH} 2^{\mathrm{R} 172 \mathrm{~K}}$ leukemic cells treated with shRen or shIDH2.

Here we demonstrate that the $\mathrm{IDH} 2^{\mathrm{R} 140 \mathrm{Q}}$ and $\mathrm{IDH} 2^{\mathrm{R} 172 \mathrm{~K}}$ mutants observed in human cancers can be potent oncogenes in mice, acting as class II driver mutations that cooperate with the class I mutations Flt3-ITD and $\mathrm{Nras}^{\mathrm{G} 12 \mathrm{D}}$ to promote aggressive AML. Murine AMLs expressing IDH2 mutants display the histopathological and molecular features that are characteristic of the human disease and show a marked chemoresistance phenotype that may underlie the association between $\mathrm{IDH} 2^{\mathrm{R} 172}$ mutations and poor patient survival.

IDH2 mutant proteins promote AML by blocking the differentiation of HSPCs; in the absence of a cooperating event, this produces an MDS-like state, a disorder in which IDH2 mutations are frequent in humans (Patnaik et al. 2012). While these effects correlate with the ability of IDH2 mutants to produce 2-HG and alter DNA methylation, our experiments do not prove a causal role for these downstream changes and disease etiology or maintenance. Still, in a parallel study (Lu et al. 2013), $\mathrm{IDH} 2^{\mathrm{R} 172 \mathrm{~K}}$ acts similarly to drive the malignant conversion of mesenchymal progenitor cells into sarcoma in vivo, which also correlates with its ability to produce 2-HG, block differentiation, and alter DNA methylation. Irrespective of the precise mechanism, these data imply a broad and potent action of IDH mutant oncogenes across diverse disease states. 
Chen et al.

A

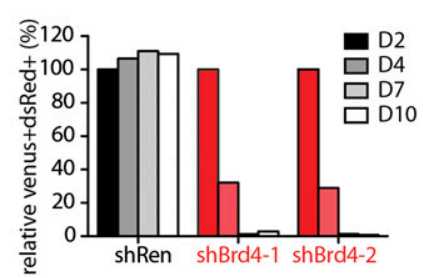

B

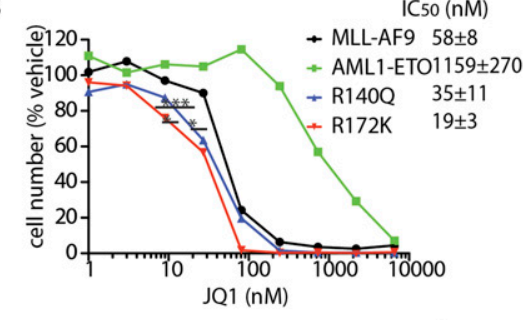

E

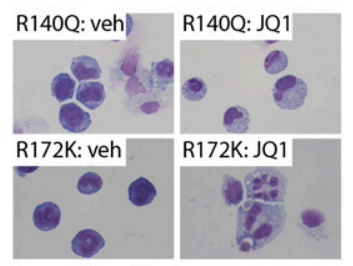

$\mathrm{H}$

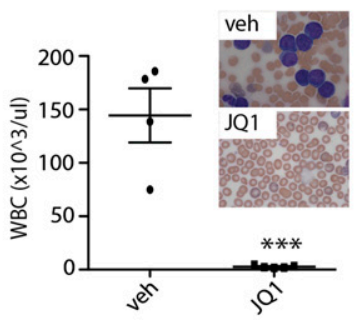

I

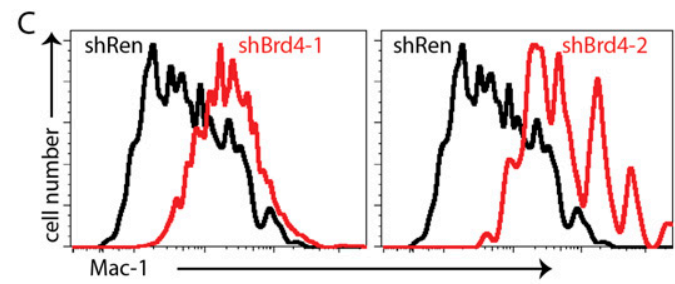

D

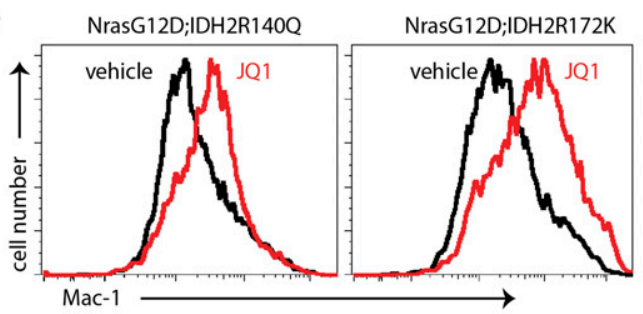

G
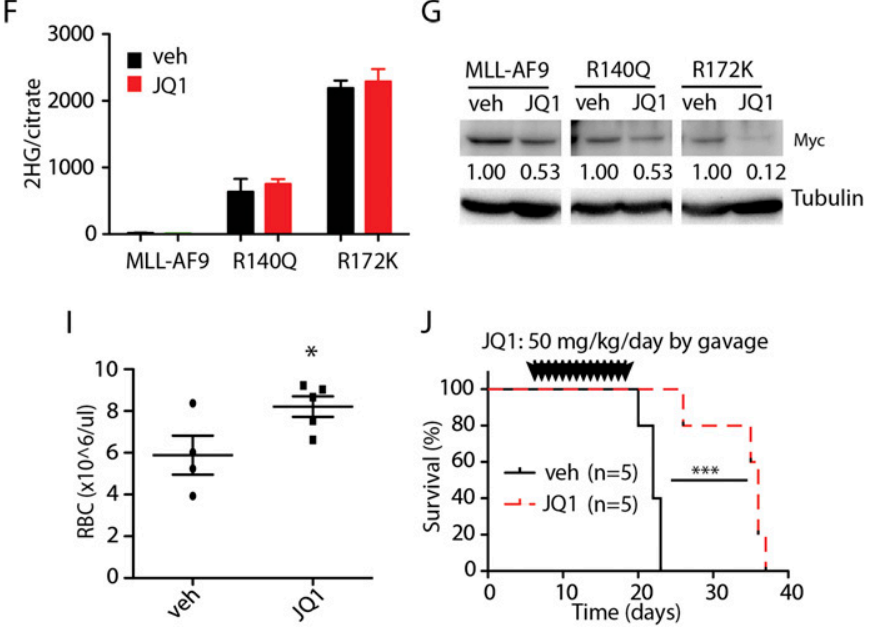

J

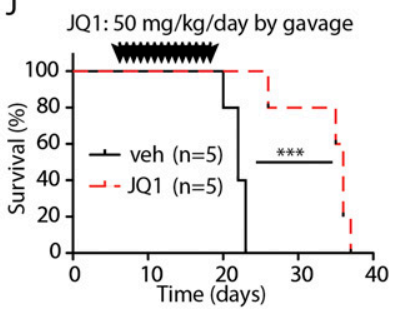

Figure 7. IDH mutant leukemias rapidly differentiate in response to Brd4 inhibition. (A) Relative growth of $\mathrm{Nras}^{\mathrm{G} 12 \mathrm{D}} ; \mathrm{IDH} 2^{\mathrm{R} 172 \mathrm{~K}}$ leukemic cells with Brd4 knockdown. $n=3$. (B) Dose response of $\operatorname{Nras}^{\mathrm{G} 12 \mathrm{D}}{ }_{\text {;MLL-AF9, Nras }}^{\mathrm{G} 12 \mathrm{D}}{ }_{\text {;AML1-ETO, Nras }}{ }^{\mathrm{G} 12 \mathrm{D}}{ }_{\text {;DH }}{ }^{\mathrm{R} 140 \mathrm{Q}}{ }^{\mathrm{A}}$, and $\mathrm{Nras}^{\mathrm{G} 12 \mathrm{D}}$;IDH2 ${ }^{\mathrm{R} 172 \mathrm{~K}}$ to JQ1. Leukemic cells were treated with vehicle or $1-6000 \mathrm{nM} \mathrm{JQ1}$ for $3 \mathrm{~d}$. $n=4$. $(C)$ Representative flow plots showing Mac-1 expression levels in Nras ${ }^{\mathrm{G} 12 \mathrm{D}}{ }_{j} \mathrm{IDH} 2^{\mathrm{R} 172 \mathrm{~K}}$ leukemic cells with shRen or shBrd4 $3 \mathrm{~d}$ after doxycycline induction. $(D)$ Representative flow plots showing Mac-1 expression levels in Nras ${ }^{\mathrm{G} 12 \mathrm{D}}{ }_{;} \mathrm{IDH} 2^{\mathrm{R} 140 \mathrm{Q}}$ and $\mathrm{Nras}^{\mathrm{G} 12 \mathrm{D}} ; \mathrm{IDH} 2^{\mathrm{R} 172 \mathrm{~K}}$ leukemic cells treated with vehicle or $50 \mathrm{nM} J Q 1$ for $2 \mathrm{~d}$. (E) Representative cytospin staining of Nras ${ }^{\mathrm{G} 12 \mathrm{D}}$;IDH2 ${ }^{\mathrm{R} 140 \mathrm{Q}}$ and $\mathrm{Nras}^{\mathrm{G} 12 \mathrm{D}} ; \mathrm{IDH} 2^{\mathrm{R} 172 \mathrm{~K}}$ leukemic cells treated with vehicle or $50 \mathrm{nM}$ JQ1 for $2 \mathrm{~d}$. $(F) 2$ - $\mathrm{HG}$ levels of Nras ${ }^{\mathrm{G} 12 \mathrm{D}} ; \mathrm{MLL}-\mathrm{AF} 9, \mathrm{Nras}^{\mathrm{G} 12 \mathrm{D}} ; \mathrm{IDH} 2^{\mathrm{R} 140 \mathrm{Q}}$, and $\mathrm{Nras}^{\mathrm{G} 12 \mathrm{D}}$;IDH2 ${ }^{\mathrm{R} 172 \mathrm{~K}}$ leukemic cells treated with vehicle or $50 \mathrm{nM}$ JQ1 for 2 d. $n=3$. $(G)$ Western blotting of Myc levels in Nras ${ }^{\text {G12D }}$;MLL-AF9, $\mathrm{Nras}^{\mathrm{G} 12 \mathrm{D}}$;IDH2 ${ }^{\mathrm{R} 140 \mathrm{Q}}$, and $\mathrm{Nras}^{\mathrm{G} 12 \mathrm{D}} ; \mathrm{IDH} 2^{\mathrm{R} 172 \mathrm{~K}}$ leukemic cells treated with vehicle or $50 \mathrm{nM}$ JQ1 for $2 \mathrm{~d}$. The numbers indicate normalized Myc levels by densitometry. $(H)$ WBC counts of Nras ${ }^{\mathrm{G} 12 \mathrm{D}}{ }_{\text {iDH }} 2^{\mathrm{R} 172 \mathrm{~K}}$ recipient mice treated with vehicle or JQ1 at day 20 after transplant. Inserts show the representative blood smear of vehicle- or JQ1-treated mice. Vehicle, $n=4 ; \mathrm{JQ1}, n=5$. (I) RBC counts of $\mathrm{Nras}^{\mathrm{G} 12 \mathrm{D}}$;IDH2 ${ }^{\mathrm{R} 172 \mathrm{~K}}$ recipient mice treated with vehicle or JQ1 $20 \mathrm{~d}$ after transplant. Vehicle, $n=4$; JQ1, $n=5$. (J) Kaplan-Meier survival curve of $\mathrm{Nras}^{\mathrm{G} 12 \mathrm{D}} ; \mathrm{IDH} 2^{\mathrm{R} 172 \mathrm{~K}}$ recipient mice treated with vehicle or JQ1. The mice were treated with vehicle or $50 \mathrm{mg} / \mathrm{kg}$ per day JQ1 by gavage from day 5 to day 18 after transplant. $n=5$.

Owing to their similarity to the human disease, the AML models described herein may be useful for evaluating therapies to target IDH2 mutant leukemia. Using genetic and pharmacological tools to manipulate IDH2 activity, we show that IDH2 mutants are required for sustained 2-HG production and leukemia maintenance. Suppression of IDH2 mutant levels and its neomorphic activity triggered myeloid differentiation, albeit requiring prolonged IDH2 inhibition. This delayed response may reflect the requirement for multiple rounds of proliferation to restore normal epigenetic states but might also present a confounding factor when treating patients with acute leukemia. In contrast, shRNA or small-moleculemediated inhibition of Brd4 causes rapid terminal differentiation and elimination of IDH2 mutant leukemia cells even in the presence of sustained 2-HG levels. This effect is associated with loss of a Myc-dependent self-renewal circuit and triggers substantial anti-leukemic effects in vivo. Notably, IDH2 ${ }^{\mathrm{R} 172 \mathrm{~K}}$ mutant $\mathrm{AML}$, which is not inhibited by AGI6780 (Wang et al. 2013) and is associated with poor prognosis (Marcucci et al. 2010; Paschka et al. 2010; Patel et al. 2012), displays the highest sensitivity to Brd4 inhibition.

While high-dose chemotherapy can be highly effective against AML, these agents produce substantial toxicity, 
and patients frequently relapse with resistant disease. One notable exception involves the treatment of acute promyelocytic leukemia (APL), which can be cured without substantial toxicity by a combination of all trans retinoic acid (ATRA) together with arsenic or other molecularly targeted agents (Shen et al. 1997). In contrast to conventional chemotherapy, which triggers leukemia cell death, ATRA acts more directly by reversing the differentiation block produced by the driving PML-RAR $\alpha$ oncoprotein (Zhang et al. 2000). As shown here, similar effects can be achieved in murine IDH2 mutant AMLs following IDH2 or Brd4 inhibition, raising hope that improved agents will produce sustained anti-leukemic responses in patients. In any event, these observations validate IDH2 as a therapeutic target in AML and point to an alternative approach to IDH2 inhibition for treatment of IDH2 mutant cancers.

\section{Materials and methods}

\section{Mice}

All mouse experiments were conducted in accordance with institutional guidelines at Memorial Sloan-Kettering Cancer Center (MSKCC). Recipient C57Bl/6 mice (National Cancer Institute) were irradiated at a dose of $4.5 \mathrm{~Gy}$ (Cs137) for sublethal irradiation or two doses of $5.5 \mathrm{~Gy}$ for lethal irradiation before transplantation. Mice were transplanted with $1 \times$ $10^{6}$ or the indicated number of cells by tail vein injection. Mice were monitored for leukemogenesis by complete blood cell count (Hemavet, Drew Scientific), spleen palpation, and blood smear.

\section{Plasmid construction}

Human IDH2 wild type and mutants R140Q and R172K were cloned into a pMIG vector (Lu et al. 2012). shRNAs against Renilla (TGCTGTTGACAGTGAGCGCAGGAATTATAATGC TTATCTATAGTGAAGCCACAGATGTATAGATAAGCATTA TAATTCCTATGCCTACTGCCTCGGA), IDH2 (shIDH-1, TGC TGTTGACAGTGAGCGCCAAGCTGAAGAAGATGTGGAA TAGTGAAGCCACAGATGTATTCCACATCTTCTTCAGCTT GATGCCTACTGCCTCGGA; shIDH2-2, TGCTGTTGACA GTGAGCGCTAAGACCGACTTCGACAAGAATAGTGAA GCCACAGATGTATTCTTGTCGAAGTCGGTCTTATTGCCT ACTGCCTCGGA), and Brd4 (shBrd4-1, TGCTGTTGACAGTG AGCGCCCCATGGATATGGGAACAATATAGTGAAGCCACA GATGTATATTGTTCCCATATCCATGGGTTGCCTACTGCCT CGGA; shBrd4-2:,TGCTGTTGACAGTGAGCGACACAATCAA GTCTAAACTAGATAGTGAAGCCACAGATGTATCTAGTTTA GACTTGATTGTGCTGCCTACTGCCTCGGA) (Zuber et al. 2011b) were cloned into a TRIN (Tre-dsRed-mir30-PGK-VenusIRES-Neo) vector (Zuber et al. 2011a).

\section{Cell culture and transduction}

BM cells were isolated from the indicated young adult donor mice, and c-kit-positive HSPCs were separated by autoMACS (Miltenyi Biotec, Inc.). HSPCs were cultured with stem cell medium as described (Schmitt et al. 2002; Zuber et al. 2009). IDH2 mutant AMLs were cultured with IMDM medium supplemented with $20 \%$ FBS and $0.2 \mathrm{ng} / \mathrm{mL}$ IL-3. Nras ${ }^{\mathrm{G} 12 \mathrm{D}}$;MLL-AF9 AML was cultured with RPMI-1640 plus $10 \%$ FBS. Retroviruses were made by calcium phosphate-mediated transfection of
Plat-E (Morita et al. 2000) packaging cells. HSPCs and AML cells were transfected by spinoculation.

\section{Measurement of 2-HG}

Frozen cell pellets were extracted with $1 \mathrm{~mL}$ of ice-cold $80 \%$ methanol containing $20 \mu \mathrm{M}$ deuterated 2 -HG as an internal standard (D-hydroxyglutaric-2,3,3,4,4-d5). Methanol extracts were incubated at $-80^{\circ} \mathrm{C}$ for $30 \mathrm{~min}$ and centrifuged at $21,000 \mathrm{~g}$ for $20 \mathrm{~min}$ at $4^{\circ} \mathrm{C}$ to remove precipitated protein. Nine-hundred microliters was evaporated to dryness under a nitrogen gas stream. Dried organic acids were derivatized by the sequential addition of $50 \mu \mathrm{L}$ of $40 \mathrm{mg} / \mathrm{mL}$ methoxyamine hydrochloride in pyridine with incubation for $90 \mathrm{~min}$ at $30^{\circ} \mathrm{C}$ followed by $80 \mu \mathrm{L}$ of MSTFA $+1 \%$ TMCS (Thermo Scientific) and $70 \mu \mathrm{L}$ of ethyl acetate with incubation for $30 \mathrm{~min}$ at $37^{\circ} \mathrm{C}$ using an automated sample preparation platform (Gerstel). One microliter of the trimethylsilyl-derivatized organic acids was analyzed by GC-MS using an Agilent 7890A gas chromatograph with an HP-5MS capillary column connected to an Agilent 5975 C mass selective detector operating in splitless mode with electron impact ionization. Relative quantitation of 2-HG was determined from extracted ion chromatograms (EICs) for 2-HG (m/z: 349 or 247) normalized to the EICs of intracellular citrate (m/z: 465).

\section{Histology and pathology assay}

Bone, spleen, and liver were fixed in $10 \%$ formalin. Embedding, sectioning, and H\&E staining were performed by IDEXX RADIL. Blood smears were stained with Hema-Quik II stain solution (Fisher Scientific). Cytospin was performed on Shandon Cytospin 4 and then stained with JorVet DipQuick stain.

\section{Flow cytometry}

Flow cytometry was performed on LSR II or Fortessa machines (BD Bioscience). All of the cell surface marker antibodies were from eBioscience. 5-hmC antibodies were from Active Motif (no. 39769). Cell surface marker staining was performed with Hank's balanced salt solution plus $2 \%$ FBS. For 5 -hmC staining, cells were fixed and permeabilized with BD fix/perm buffer and then treated with $0.3 \mathrm{mg} / \mathrm{mL}$ DNase I for $30 \mathrm{~min}$ at $37^{\circ} \mathrm{C}$. For the BrdU incorporation assay, mice were intraperitoneally (i.p.) injected with $100 \mathrm{mg} / \mathrm{kg} \mathrm{BrdU}$ and then fed with $1 \mathrm{mg} / \mathrm{mL}$ BrdU in water for $24 \mathrm{~h}$ (Chen et al. 2008). BrdU staining was performed with a BD BrdU kit (BD Bioscience).

\section{Dot blotting}

Dot blotting was performed as described (Ko et al. 2010). Briefly, purified genomic DNA was quantified on NanoDrop and denatured by $0.1 \mathrm{M} \mathrm{NaOH}$. Serial-diluted DNA was spotted on a nitrocellulose membrane. $5 \mathrm{mC}$ and $5 \mathrm{hmC}$ antibodies (Active Motif) were diluted at 1:1000 and 1:5000, respectively.

\section{Western blotting}

For IDH2 and Myc detection, cells were lysed in RIPA buffer, and lysates were separated with SDS-PAGE gel electrophoresis. For histone acid extraction, cells were lysed in hypotonic lysis buffer. The primary antibodies were anti-IDH2 (Abcam, ab55271), antic-Myc (Santa Cruz Biotechnology, sc-764), anti-actin (Sigma, T6074), anti-tubulin (Sigma, T9026), anti-H3K4me3 (Active Motif, 39916), anti-H3K9me3 (Active Motif, 39765), anti-H3K27me3 (Millipore, 07-449), and anti-H3 (Cell Signaling Tech, 4499). 


\section{Quantitative real-time PCR}

mRNA was extracted from FACS-sorted cells with Trizol (Invitrogen), and then cDNA was made with SuperScript III (Invitrogen) according to the manufacturer's manual. Quantitative PCR was performed on a 7900HT Fast Real-Time system (Applied Biosystems). The sequences of PCR primers were mouse Actin forward (TGGTGATAAGTGGCCTTGGAGTGT) and reverse (ATGCAAGGAGTGCAAGAACACAGC) and hIDH2 forward (AGACCGACTTCGACAAGAATAAG) and reverse (GACTGC ACATCTCCGTCATAG).

\section{Two-color shRNA competitive proliferation assay}

Cells were transduced with shRNAs and then selected with G418 (US Biological). Infected cells were mixed with uninfected cells at a 1:1 ratio for the IDH2 knockdown experiment and 4:1 for the Brd4 knockdown experiment. Next, the shRNAs were induced by $1 \mathrm{mg} / \mathrm{mL}$ doxycycline (Sigma). The percentage of shRNA-expressing cells $\left(\right.$ Venus $\left.^{+} \mathrm{dsRed}^{+}\right)$was measured by a Guava easyCyte flow cytometer (Millipore) at the indicated time points.

\section{Drug treatment}

In vitro, cells were treated with vehicle, ara-C (Bedford Laboratories), AGI-6780 (Xcess Biosciences), or JQ1 for $3 \mathrm{~d}$ or the indicated times. Viable cells were counted by a Guava easyCyte flow cytometer. For in vivo treatment, JQ1 was suspended in vehicle $(0.5 \%[\mathrm{w} / \mathrm{v}]$ hydroxy-propyl-methylcellulose [Sigma], $0.2 \%[\mathrm{v} / \mathrm{v}]$ Tween 80 [Sigma]) at a concentration of $10 \mathrm{mg} / \mathrm{mL}$. The suspension was sonicated before use. Mice with AMLs were treated with vehicle, $100 \mathrm{mg} / \mathrm{kg}$ per day ara-C by i.p. injection for $5 \mathrm{~d}$, or $50 \mathrm{mg} / \mathrm{kg}$ per day JQ1 by gavage for $2 \mathrm{wk}$.

\section{Acknowledgments}

We thank C.C. Sherr, Dr. Z. Zhao, Dr. C. Miething, Dr. C. Chen, and other members of the Lowe laboratory for suggestions and/or technical help; S. Kogan for histopathological analysis; C. Sherr, L. Dow, and S. Mayack for editorial assistance; and T. Jacks for the Nras ${ }^{\text {G12D }}$ mice. C.C. was supported by a career development fellowship from the Leukemia and Lymphoma Society (LLS). This work was supported by a Specialized Center of Research (SCOR) grant from the LLS (to S.W.L.) and a U01 CTDD award from the National Cancer Institute (to S.W.L.). S.W.L. is the Goeffrey Beene Chair of Cancer Biology at MSKCC and an Investigator in the Howard Hughes Medical Institute.

\section{References}

Amary MF, Bacsi K, Maggiani F, Damato S, Halai D, Berisha F, Pollock R, O'Donnell P, Grigoriadis A, Diss T, et al. 2011. IDH1 and IDH2 mutations are frequent events in central chondrosarcoma and central and periosteal chondromas but not in other mesenchymal tumours. J Pathol 224: 334-343.

Bernt KM, Zhu N, Sinha AU, Vempati S, Faber J, Krivtsov AV, Feng Z, Punt N, Daigle A, Bullinger L, et al. 2011. MLLrearranged leukemia is dependent on aberrant H3K79 methylation by DOT1L. Cancer Cell 20: 66-78.

The Cancer Genome Atlas Research Network. 2013. Genomic and epigenomic landscapes of adult de novo acute myeloid leukemia. N Engl J Med 368: 2059-2074.

Chen C, Liu Y, Liu R, Ikenoue T, Guan KL, Zheng P. 2008. TSCmTOR maintains quiescence and function of hematopoietic stem cells by repressing mitochondrial biogenesis and reactive oxygen species. J Exp Med 205: 2397-2408.
Chu SH, Heiser D, Li L, Kaplan I, Collector M, Huso D, Sharkis SJ, Civin C, Small D. 2012. FLT3-ITD knockin impairs hematopoietic stem cell quiescence/homeostasis, leading to myeloproliferative neoplasm. Cell Stem Cell 11: 346-358.

Daigle SR, Olhava EJ, Therkelsen CA, Majer CR, Sneeringer CJ, Song J, Johnston LD, Scott MP, Smith JJ, Xiao Y, et al. 2011. Selective killing of mixed lineage leukemia cells by a potent small-molecule DOT1L inhibitor. Cancer Cell 20: 53-65.

Dang L, White DW, Gross S, Bennett BD, Bittinger MA, Driggers EM, Fantin VR, Jang HG, Jin S, Keenan MC, et al. 2009. Cancer-associated IDH1 mutations produce 2-hydroxyglutarate. Nature 462: 739-744.

Dawson MA, Prinjha RK, Dittmann A, Giotopoulos G, Bantscheff M, Chan WI, Robson SC, Chung CW, Hopf C, Savitski MM, et al. 2011. Inhibition of BET recruitment to chromatin as an effective treatment for MLL-fusion leukaemia. Nature 478: 529-533.

Figueroa ME, Abdel-Wahab O, Lu C, Ward PS, Patel J, Shih A, Li Y, Bhagwat N, Vasanthakumar A, Fernandez HF, et al. 2010. Leukemic IDH1 and IDH2 mutations result in a hypermethylation phenotype, disrupt TET2 function, and impair hematopoietic differentiation. Cancer Cell 18: 553-567.

Filippakopoulos P, Qi J, Picaud S, Shen Y, Smith WB, Fedorov O, Morse EM, Keates T, Hickman TT, Felletar I, et al. 2010. Selective inhibition of BET bromodomains. Nature 468: 1067-1073.

Haigis KM, Kendall KR, Wang Y, Cheung A, Haigis MC, Glickman JN, Niwa-Kawakita M, Sweet-Cordero A, Sebolt-Leopold J, Shannon KM, et al. 2008. Differential effects of oncogenic $\mathrm{K}-\mathrm{R}$ as and N-Ras on proliferation, differentiation and tumor progression in the colon. Nat Genet 40: 600-608.

Kelly LM, Gilliland DG. 2002. Genetics of myeloid leukemias. Annu Rev Genomics Hum Genet 3: 179-198.

Ko M, Huang Y, Jankowska AM, Pape U,, Tahiliani M, Bandukwala HS, An J, Lamperti ED, Koh KP, Ganetzky R, et al. 2010. Impaired hydroxylation of 5-methylcytosine in myeloid cancers with mutant TET2. Nature 468: 839-843.

Koivunen P, Lee S, Duncan CG, Lopez G, Lu G, Ramkissoon S, Losman JA, Joensuu P, Bergmann U, Gross S, et al. 2012. Transformation by the (R)-enantiomer of 2-hydroxyglutarate linked to EGLN activation. Nature 483: 484-488.

Lauchle JO, Kim D, Le DT, Akagi K, Crone M, Krisman K, Warner K, Bonifas JM, Li Q, Coakley KM, et al. 2009. Response and resistance to MEK inhibition in leukaemias initiated by hyperactive Ras. Nature 461: 411-414.

Lee BH, Tothova Z, Levine RL, Anderson K, Buza-Vidas N, Cullen DE, McDowell EP, Adelsperger J, Frohling S, Huntly BJ, et al. 2007. FLT3 mutations confer enhanced proliferation and survival properties to multipotent progenitors in a murine model of chronic myelomonocytic leukemia. Cancer Cell 12: 367-380.

Leung AY, Man CH, Kwong YL. 2013. FLT3 inhibition: A moving and evolving target in acute myeloid leukaemia. Leukemia 27: 260-268.

Li Q, Haigis KM, McDaniel A, Harding-Theobald E, Kogan SC, Akagi K, Wong JC, Braun BS, Wolff L, Jacks T, et al. 2011. Hematopoiesis and leukemogenesis in mice expressing oncogenic NrasG12D from the endogenous locus. Blood 117: 2022-2032.

Losman JA, Looper RE, Koivunen P, Lee S, Schneider RK, McMahon C, Cowley GS, Root DE, Ebert BL, Kaelin WG Jr. 2013. (R)-2-hydroxyglutarate is sufficient to promote leukemogenesis and its effects are reversible. Science 339: 1621-1625.

Lu C, Ward PS, Kapoor GS, Rohle D, Turcan S, Abdel-Wahab O, Edwards CR, Khanin R, Figueroa ME, Melnick A, et al. 2012. 
IDH mutation impairs histone demethylation and results in a block to cell differentiation. Nature 483: 474-478.

Lu C, Venneti S, Akalin A, Fang F, Ward PS, DeMatteo RG, Intlekofer AM, Chen C, Ye J, Hameed M, et al. 2013. Induction of sarcomas by mutant IDH2. Genes Dev (this issue). doi: 10.1101/gad.226753.113.

Marcucci G, Maharry K, Wu YZ, Radmacher MD, Mrozek K, Margeson D, Holland KB, Whitman SP, Becker H, Schwind S, et al. 2010. IDH1 and IDH2 gene mutations identify novel molecular subsets within de novo cytogenetically normal acute myeloid leukemia: A Cancer and Leukemia Group B study. J Clin Oncol 28: 2348-2355.

Mardis ER, Ding L, Dooling DJ, Larson DE, McLellan MD, Chen K, Koboldt DC, Fulton RS, Delehaunty KD, McGrath SD, et al. 2009. Recurring mutations found by sequencing an acute myeloid leukemia genome. N Engl I Med 361: 10581066.

Matzuk MM, McKeown MR, Filippakopoulos P, Li Q, Ma L, Agno JE, Lemieux ME, Picaud S, Yu RN, Qi J, et al. 2012. Small-molecule inhibition of BRDT for male contraception. Cell 150: 673-684.

Morita S, Kojima T, Kitamura T. 2000. Plat-E: An efficient and stable system for transient packaging of retroviruses. Gene Ther 7: 1063-1066.

Nakao M, Yokota S, Iwai T, Kaneko H, Horiike S, Kashima K, Sonoda Y, Fujimoto T, Misawa S. 1996. Internal tandem duplication of the flt 3 gene found in acute myeloid leukemia. Leukemia 10: 1911-1918.

Parsons DW, Jones S, Zhang X, Lin JC, Leary RJ, Angenendt P, Mankoo P, Carter H, Siu IM, Gallia GL, et al. 2008. An integrated genomic analysis of human glioblastoma multiforme. Science 321: 1807-1812.

Paschka P, Schlenk RF, Gaidzik VI, Habdank M, Kronke J, Bullinger L, Spath D, Kayser S, Zucknick M, Gotze K, et al. 2010. IDH1 and IDH2 mutations are frequent genetic alterations in acute myeloid leukemia and confer adverse prognosis in cytogenetically normal acute myeloid leukemia with NPM1 mutation without FLT3 internal tandem duplication. J Clin Oncol 28: 3636-3643.

Patel JP, Gonen M, Figueroa ME, Fernandez H, Sun Z, Racevskis J, Van Vlierberghe P, Dolgalev I, Thomas S, Aminova O, et al. 2012. Prognostic relevance of integrated genetic profiling in acute myeloid leukemia. N Engl J Med 366: 1079-1089.

Patnaik MM, Hanson CA, Hodnefield JM, Lasho TL, Finke CM, Knudson RA, Ketterling RP, Pardanani A, Tefferi A. 2012. Differential prognostic effect of IDH1 versus IDH2 mutations in myelodysplastic syndromes: A Mayo Clinic study of 277 patients. Leukemia 26: 101-105.

Rohle D, Popovici-Muller J, Palaskas N, Turcan S, Grommes C, Campos C, Tsoi J, Clark O, Oldrini B, Komisopoulou E, et al. 2013. An inhibitor of mutant IDH1 delays growth and promotes differentiation of glioma cells. Science 340: 626630.

Sasaki M, Knobbe CB, Munger JC, Lind EF, Brenner D, Brustle A, Harris IS, Holmes R, Wakeham A, Haight J, et al. 2012. IDH1 $(\mathrm{R} 132 \mathrm{H})$ mutation increases murine haematopoietic progenitors and alters epigenetics. Nature 488: 656-659.

Schmitt CA, Fridman JS, Yang M, Baranov E, Hoffman RM, Lowe SW. 2002. Dissecting p53 tumor suppressor functions in vivo. Cancer Cell 1: 289-298.

Schubbert S, Shannon K, Bollag G. 2007. Hyperactive Ras in developmental disorders and cancer. Nat Rev Cancer 7: 295308.

Shen ZX, Chen GQ, Ni JH, Li XS, Xiong SM, Qiu QY, Zhu J, Tang W, Sun GL, Yang KQ, et al. 1997. Use of arsenic trioxide $\left(\mathrm{As}_{2} \mathrm{O}_{3}\right)$ in the treatment of acute promyelocytic leukemia
(APL): II. Clinical efficacy and pharmacokinetics in relapsed patients. Blood 89: 3354-3360.

Shih AH, Abdel-Wahab O, Patel JP, Levine RL. 2012. The role of mutations in epigenetic regulators in myeloid malignancies. Nat Rev Cancer 12: 599-612.

Stirewalt DL, Radich JP. 2003. The role of FLT3 in haematopoietic malignancies. Nat Rev Cancer 3: 650-665.

Takahashi S. 2011. Current findings for recurring mutations in acute myeloid leukemia. J Hematol Oncol 4: 36.

Turcan S, Rohle D, Goenka A, Walsh LA, Fang F, Yilmaz E, Campos C, Fabius AW, Lu C, Ward PS, et al. 2012. IDH1 mutation is sufficient to establish the glioma hypermethylator phenotype. Nature 483: 479-483.

Wang J, Liu Y, Li Z, Wang Z, Tan LX, Ryu MJ, Meline B, Du J, Young KH, Ranheim E, et al. 2011. Endogenous oncogenic Nras mutation initiates hematopoietic malignancies in a dose- and cell type-dependent manner. Blood 118: 368-379.

Wang F, Travins J, DeLaBarre B, Penard-Lacronique V, Schalm S, Hansen E, Straley K, Kernytsky A, Liu W, Gliser C, et al. 2013. Targeted inhibition of mutant IDH2 in leukemia cells induces cellular differentiation. Science 340: 622-626.

Ward PS, Patel J, Wise DR, Abdel-Wahab O, Bennett BD, Coller HA, Cross JR, Fantin VR, Hedvat CV, Perl AE, et al. 2010. The common feature of leukemia-associated IDH1 and IDH2 mutations is a neomorphic enzyme activity converting $\alpha$-ketoglutarate to 2-hydroxyglutarate. Cancer Cell 17: 225234.

Ward PS, Lu C, Cross JR, Abdel-Wahab O, Levine RL, Schwartz GK, Thompson CB. 2013. The potential for isocitrate dehydrogenase mutations to produce 2-hydroxyglutarate depends on allele specificity and subcellular compartmentalization. J Biol Chem 288: 3804-3815.

Xu W, Yang H, Liu Y, Yang Y, Wang P, Kim SH, Ito S, Yang C, Xiao MT, Liu LX, et al. 2011. Oncometabolite 2-hydroxyglutarate is a competitive inhibitor of $\alpha$-ketoglutarate-dependent dioxygenases. Cancer Cell 19: 17-30.

Yan H, Parsons DW, Jin G, McLendon R, Rasheed BA, Yuan W, Kos I, Batinic-Haberle I, Jones S, Riggins GJ, et al. 2009. IDH1 and IDH2 mutations in gliomas. N Engl J Med 360: 765-773.

Zhang JW, Wang JY, Chen SJ, Chen Z. 2000. Mechanisms of alltrans retinoic acid-induced differentiation of acute promyelocytic leukemia cells. J Biosci 25: 275-284.

Zuber J, Radtke I, Pardee TS, Zhao Z, Rappaport AR, Luo W, McCurrach ME, Yang MM, Dolan ME, Kogan SC, et al. 2009. Mouse models of human AML accurately predict chemotherapy response. Genes Dev 23: 877-889.

Zuber J, McJunkin K, Fellmann C, Dow LE, Taylor MJ, Hannon GJ, Lowe SW. 2011a. Toolkit for evaluating genes required for proliferation and survival using tetracycline-regulated RNAi. Nat Biotechnol 29: 79-83.

Zuber J, Shi J, Wang E, Rappaport AR, Herrmann H, Sison EA, Magoon D, Qi J, Blatt K, Wunderlich M, et al. 2011b. RNAi screen identifies Brd4 as a therapeutic target in acute myeloid leukaemia. Nature 478: 524-528. 


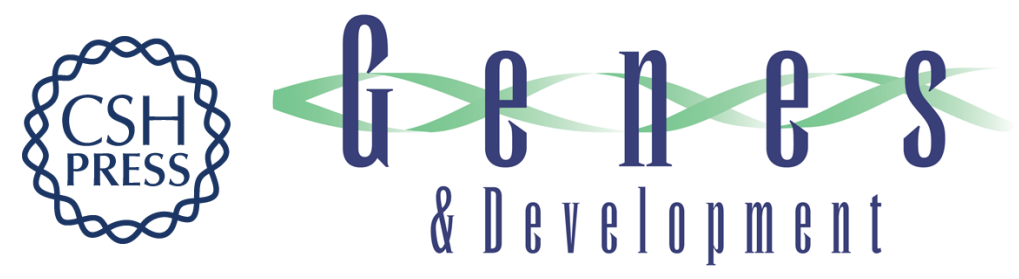

\title{
Cancer-associated IDH2 mutants drive an acute myeloid leukemia that is susceptible to Brd4 inhibition
}

\author{
Chong Chen, Yu Liu, Chao Lu, et al.
}

Genes Dev. 2013, 27:

Access the most recent version at doi:10.1101/gad.226613.113

\section{Supplemental http://genesdev.cshlp.org/content/suppl/2013/09/24/27.18.1974.DC1 Material}

References This article cites 48 articles, 12 of which can be accessed free at: http://genesdev.cshlp.org/content/27/18/1974.full.html\#ref-list-1

Creative This article is distributed exclusively by Cold Spring Harbor Laboratory Press for the first Commons six months after the full-issue publication date (see

License http://genesdev.cshlp.org/site/misc/terms.xhtml). After six months, it is available under a Creative Commons License (Attribution-NonCommercial 3.0 Unported), as described at http://creativecommons.org/licenses/by-nc/3.0/.

Email Alerting Receive free email alerts when new articles cite this article - sign up in the box at the top Service right corner of the article or click here.

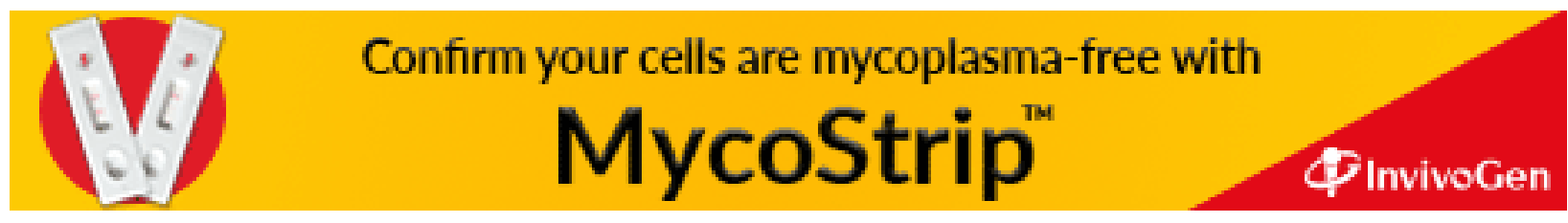

